\title{
Using high-resolution stratigraphy and structural analysis to constrain polyphase tectonics in wedge-top basins: Inferences from the late Tortonian Scillato Basin (central-northern Sicily)
}

\author{
C. Gugliotta ${ }^{\text {a }, ~ M . ~ G a s p a r o ~ M o r t i c e l l i ~ b, * ~}$ \\ a Present address: Dipartimento di Scienze della Terra, Università degli Studi di Perugia, Piazza dell'Università, 1, 06100, Perugia, Italy \\ ${ }^{b}$ Present address: Dipartimento di Scienze della Terra e del Mare, Università degli Studi di Palermo, via Archirafi, 20, 90123, Palermo, Italy
}

\section{A R T I C L E I N F O}

\section{Article history:}

Received 25 July 2011

Received in revised form 6 June 2012

Accepted 22 June 2012

Available online 4 July 2012

Editor: G.J. Weltje

\section{Keywords}

Tectonics and sedimentation

Polyphase evolution

Deep-seated tectonics

Central-northern Sicily

Late Tortonian

Terravecchia Formation

\begin{abstract}
A B S T R A C T
The present paper aims to show, both from a stratigraphic and structural points of view, the main features of a wedge-top syntectonic basin which evolved recording polyphase and non-coaxial tectonics. The study area is the Scillato Basin $(S B)$, a roughly $\mathrm{N}-\mathrm{S}$-oriented structural depression located in the central-northern sector of the Sicililian Maghrebides. There, an approximately 1300 m-thick upper Serravallian to upper Tortonian succession of clastic units outcrops as a portion of the Neogene syntectonic covers of the Sicilian fold and thrust belt. Within the outcropping succession the upper Tortonian Terravecchia Fm represents the main topic of this paper. A multidisciplinary approach was carried out through an integration of sedimentology, facies, stratal pattern and structural analyses; this was applied to the formation enabling one to recognize in the Scillato Basin a fining to coarsening upward succession, deposited recording an early transgressive and a late regressive depositional stage. In our model these two main depositional stages developed and are directly relatable to a two-step structural evolution of the basin. During the first step, a NW-SE-oriented structural depression existed, enclosed between structural highs and accommodating the lower and middle portion of the upper Tortonian succession. Subsequently, during the second step, the NW-SE depression was non-coaxially deformed by superimposition of high-angle transpressive faults (many of which were SE-dipping), developed in response to the upward propagation of structures enucleated at deeper structural levels. This step was recorded in the basin by development of both depositional and structural interferences recognizable along the upper portion of the Scillato Basin succession. A comparison between field data and deep geophysical data interpreted at the preliminary stage, raises questions about the late Miocene geological evolution of this sector of the Sicilian chain, including: (i) the syn-tectonic deposition of the Terravecchia $\mathrm{Fm}$. in the Scillato Basin clearly recorded the interference of two main and non-coaxial tectonic events; (ii) the younger of these two events has a clear tranpressional character and was active during the very late Tortonian; (iii) as also indicated by many authors in neighboring orogenic wedges, the main control on the location, geometry and depositional evolution of the Scillato wedge-top Basin was carried out by compressional and transpressional structures developed at a deeper structural level. Their deformation propagated upward both into the shallow structural level and sedimentary covers; therefore (iv) the late Miocene structural scenario here depicted is not consistent either with the back-arc-related extension or with the late orogenic gravitational collapse models previously invoked by other authors with regard to this sector of the Sicilian thrust belt.
\end{abstract}

(c) 2012 Elsevier B.V. All rights reserved.

\section{Introduction}

During a fold and thrust belt development the deformation will propagate "in sequence" from the internal to the external zone, involving progressively deeper structural levels (Bally et al., 1966; Boyer and Elliott, 1982). It is also true that when deeper structural layers are

\footnotetext{
* Corresponding author.

E-mail addresses: carlo.gugliotta.unipg@gmail.com (C. Gugliotta), maurizio.gasparo@unipa.it (M. Gasparo Morticelli).
}

reached by deformation the latter will propagate both toward the foreland, through activation of new main thrusts, and upwards (vertically) into the already deformed and shallower structural layers. As a consequence of this, looking at each point of a fold and thrust belt, the structural arrangement derives from superimposition of deformative events developed at different structural levels and in different ages. The polyphase tectonic evolution of the fold and thrust belt will be highlighted in the field with the development of "structural" interference due to the successive superimposition and/or re-deformation of existing deformative structures. Looking at basins located above the orogenic 
wedge (in the wedge-top depozone sensu De Celles and Giles, 1996), where sedimentation occurred contemporaneously with the polyphase evolution of the thrust belt, the superposition of successive deformations can be visualized not only by the relationships among superimposed folds and faults, but also by the development of "depositional" interferences. The complex subsidence/uplift history of syntectonic-synkinematic basins exerts a marked control on facies distribution and basin fill architecture, especially if they are filled with shallow-water clastic sediments. The progressive development of syn-depositional folds and faults leads to changes in topography creating structural depressions and local reliefs affecting the sediment transport pathways, rates and spatial distribution of erosion and sediment deposition. Further complications in the depositional architecture of these basins are represented by progressive migration of depocenters, development of growth stratal patterns and the occurrence of widespread intraformational unconformities (Riba, 1976; Anadon et al., 1986; Roure et al., 1990; Zoetemeijer et al., 1992).

The study of the sedimentary evolution of syn-tectonic basins represents a powerful tool for understanding the timing and modalities of deformation in the study sector of the Sicilian chain. Due to significant differential, clockwise syn-kinematic rotations occurring during the thrust sheet emplacement (Catalano et al., 1978; Channell et al., 1980, 1990; Grasso et al., 1987; Oldow et al., 1990; Avellone and Barchi, 2003; Speranza et al., 2003; Guarnieri, 2004; Monaco and De Guidi, 2006) the tectonic structures of different ages were superimposed non-coaxially to each other, thereby facilitating the recognition of the interference pattern among successive compressional events. For these reasons the Sicilian fold-and-thrust belt represents an excellent "training ground" for studying the effects of a polyphase, non-coaxial, structural evolution. Even though the development of structural interferences has been widely documented by several authors (Roure et al., 1990; Avellone and Barchi, 2003; Avellone et al., 2010) there is no data about how this polyphase evolution was recorded as "depositional" interferences in the Late Neogene syntectonic basin fill.

In this paper a case history is presented from the middle-late Miocene Scillato wedge-top Basin, northern Sicilian fold-and-thrust belt (Fig. 1). An upper Tortonian siliciclastic succession pertaining to the Terravecchia Fm. outcrops here (Flores, 1959; Schmidt di Friedberg, 1962, 1964-65). The data presented here contributes to a new interpretation of the SB in terms of structural evolution and interplay between tectonics and sedimentation. On a wider scale, the geologic evolution of the central-northern sector of the Sicilian fold and thrust belt is discussed, with specific reference to the role played by the deep-seated transpressional tectonics vs extensional tectonics during the late Miocene.

\section{Regional framework}

The Sicilian Fold-and-Thrust Belt (SFTB) is a SE-verging, Neogene, thin-skinned thrust belt belonging to the wider Apennine-Maghrebian orogen (Fig. 1a), and interpreted as resulting from both the postcollisional convergence between Africa and Europe (Bellon et al., 1977; Dercourt et al., 1986; Dewey et al., 1989; Catalano et al., 1996, 2000) and the rollback of the subduction hinge of the Ionian lithosphere (Caputo et al., 1970; Doglioni et al., 1999).

This part of the Appenine-Maghrebian chain comprises (Fig. 1b) a stack of E and SE-verging tectonic units, locally more than $15 \mathrm{~km}$ thick, representing a subduction system composed of: 1) a complex chain, 2) a Plio-Pleistocene foredeep and 3) a partially undeformed foreland. The Sicily chain, in its turn, consists of several main elements, which are in order from the innermost: (a) a "European" element exposed in north-eastern Sicily as the western structural prolongation of the Calabrian arc (Amodio-Morelli et al., 1976; Bonardi et al., 2003); (b) a "Thetyan" element, generally known as Sicilide Unit (Ogniben, 1960, 1969; Bianchi et al., 1989; Catalano et al., 1996) consisting of Upper Jurassic to lower Miocene successions detached from their substrate; (c) a "Maghrebian" element consisting (Catalano and D'Argenio, 1982; Roure et al., 1990; Lentini et al., 1994; Catalano et al., 1996; Finetti, 2005) of deformed Permian to Oligocene successions originally deposited in different palaeogeographic domains developed in both deep-water (Imerese and Sicanian units) and shallow-water carbonate platform (Panormide and Trapanese-Saccense units) settings. The tectonic wedge is thrust on to the Iblean-Pelagian foreland exposed in SE Sicily (Iblean plateau) and is submerged in the Sicily Channel. At the same time as the compression, the Tyrrhenian Basin developed in the hinterland area in a regime mainly related to back-arc extension (Malinverno and Ryan, 1986; Roure et al., 1990; Catalano et al., 1996). A foreland basin system (sensu De Celles and Giles, 1996) migrating toward the Iblean foreland developed during the Neogene, at the front and partly above the advancing chain (Catalano et al., 1989; Oldow et al., 1990; Butler and Grasso, 1993; Nigro and Renda, 2000; Grasso, 2001; Gugliotta, 2011, 2012). Sedimentation continued at the front of the fold-and-thrust belt in a recent foredeep (Argnani, 1989; Catalano et al., 1989), at present buried beneath the frontal sector of the chain in southern Sicily and in the Gela Basin.

More specifically, during the late Miocene (late Tortonian-early Messinian) the SFTB was associated with a foreland basin system characterized in its innermost part (wedge-top depozone sensu De Celles and Giles, 1996) by syn-tectonic basins ranging from wide to quite narrow (Gugliotta, 2010, 2011, 2012) filled with continental to shallow-marine clastics (Terravecchia Fm.). The syn-tectonic basin growth record both intra-Tortonian and intra-Messinian tectonic events (Catalano and D'Argenio, 1990; Butler and Grasso, 1993; Lo Cicero et al., 1997; Abate et al., 1999; Del Ben and Guarnieri, 2000; Nigro and Renda, 2000; Guarnieri, 2004).

The orogenic wedge resulted from two main tectonic events which developed at different structural levels and age (Oldow et al., 1990; Catalano et al., 1996, 2000; Bello et al., 2000; Avellone et al., 2010). Since the middle Miocene, shallow-seated thrusts (present-day SW-verging) have affected deep-water carbonate rock bodies (Sicilide, Imerese and Sicanian units) with duplex geometry, associated with folds at present showing a NW-SE-trend (shallow-seated Event I, Catalano et al., 1996, 2000; Avellone et al., 2010). These units were detached from their basement and stacked above a partially undeformed carbonate platform body (Panormide, Trapanese and Saccense units). After the early Tortonian, S-verging, deep-seated thrusts and backthrusts, in association with E-W- to NE-SW-trending folds, affected the carbonate platform units (deep-seated Event II, Catalano et al., 1996, 2000; Avellone et al., 2010; Albanese and Sulli, 2011). The thrusting process transferred part of the deformation to the overlying thrust pile inducing its passive re-imbrication, the shortening and development of several late Miocene to Pliocene syntectonic basins (Roure et al., 1990; Bello et al., 2000; Catalano et al., 2000; Avellone et al., 2010).

\section{The Scillato Basin}

The Scillato Basin is located in the central-northern sector of the SFTB (Fig. 1b), along the western edge of the Madonie Mts. (Figs. 1c and $2 \mathrm{a}$ ). It consists of an approximately N-S-oriented structural depression (about $30 \mathrm{~km}^{2}$ wide), enclosed among major structural highs, respectively: the Rasolocollo Ridge to the north-west, (ii) the Monte dei Cervi Ridge to the east and (iii) the Rocca di Sciara Ridge to the south (Fig. 2a,b).

At the basin scale, the middle-late Miocene clastic succession outcropping in the Scillato Basin appears deformed, as a roughly N-S-oriented, asymmetric synform, which shows conspicuously deformed southern and eastern limbs and a less deformed northern limb (Fig. 2c). The major synform is dissected by NW-SE-trending faults with a short throw and showing extensional kinematic indicators. No clear evidence of syndepositional extensional tectonics has been found in the Terravecchia Fm. in contrast to documentation by Abate et al. (1999) and Giunta et al. (2000), which might make us think that the extensional structures developed after the late Tortonian, plausibly during the 


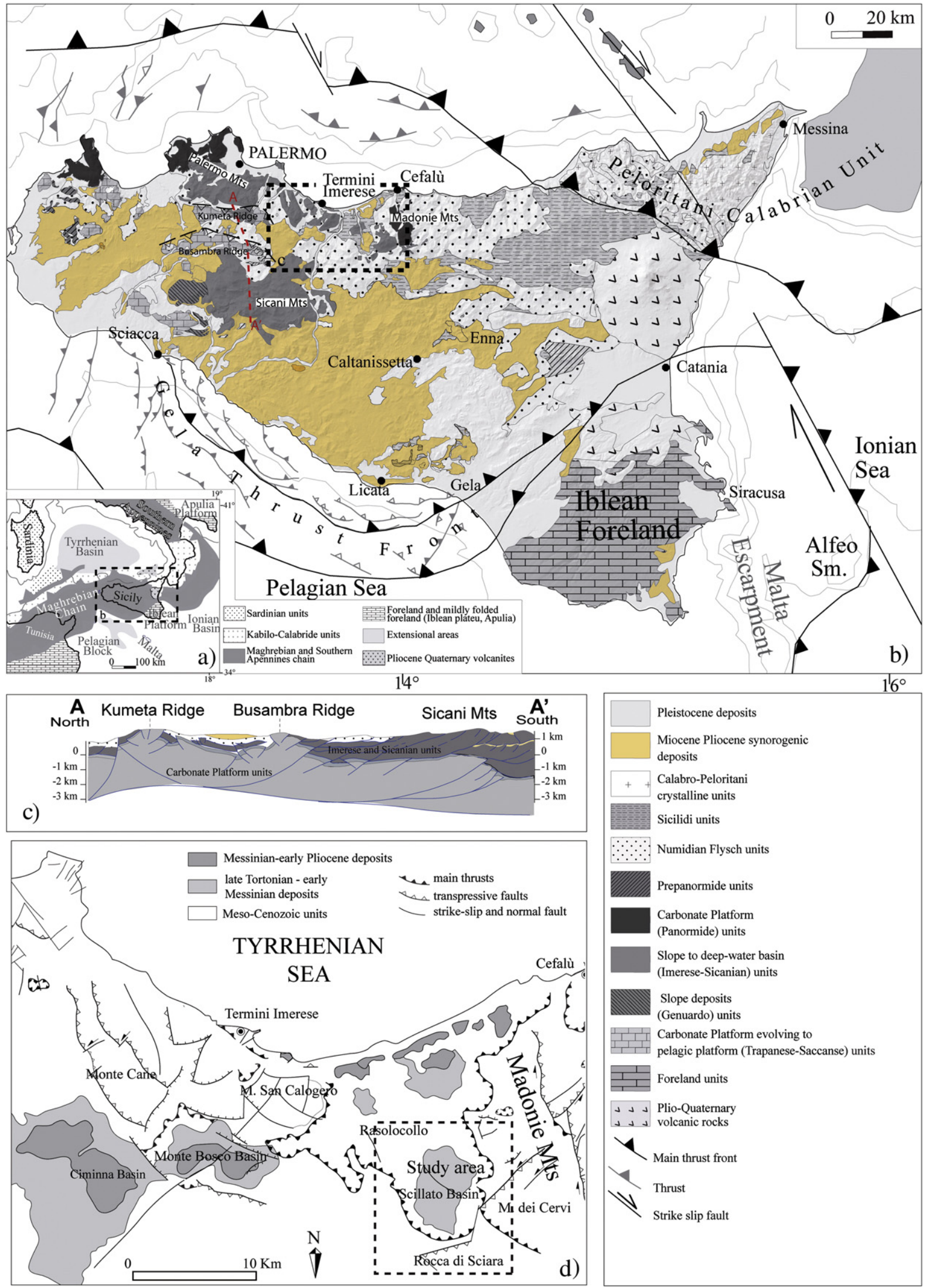

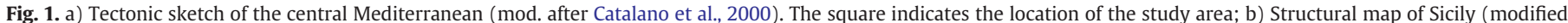

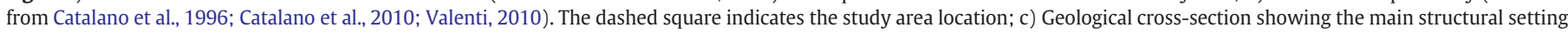

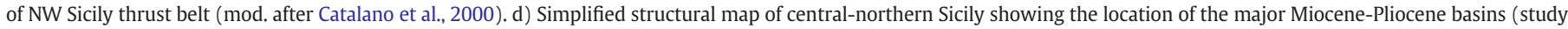
area in the dashed square) and the large-scale tectonic structures. 

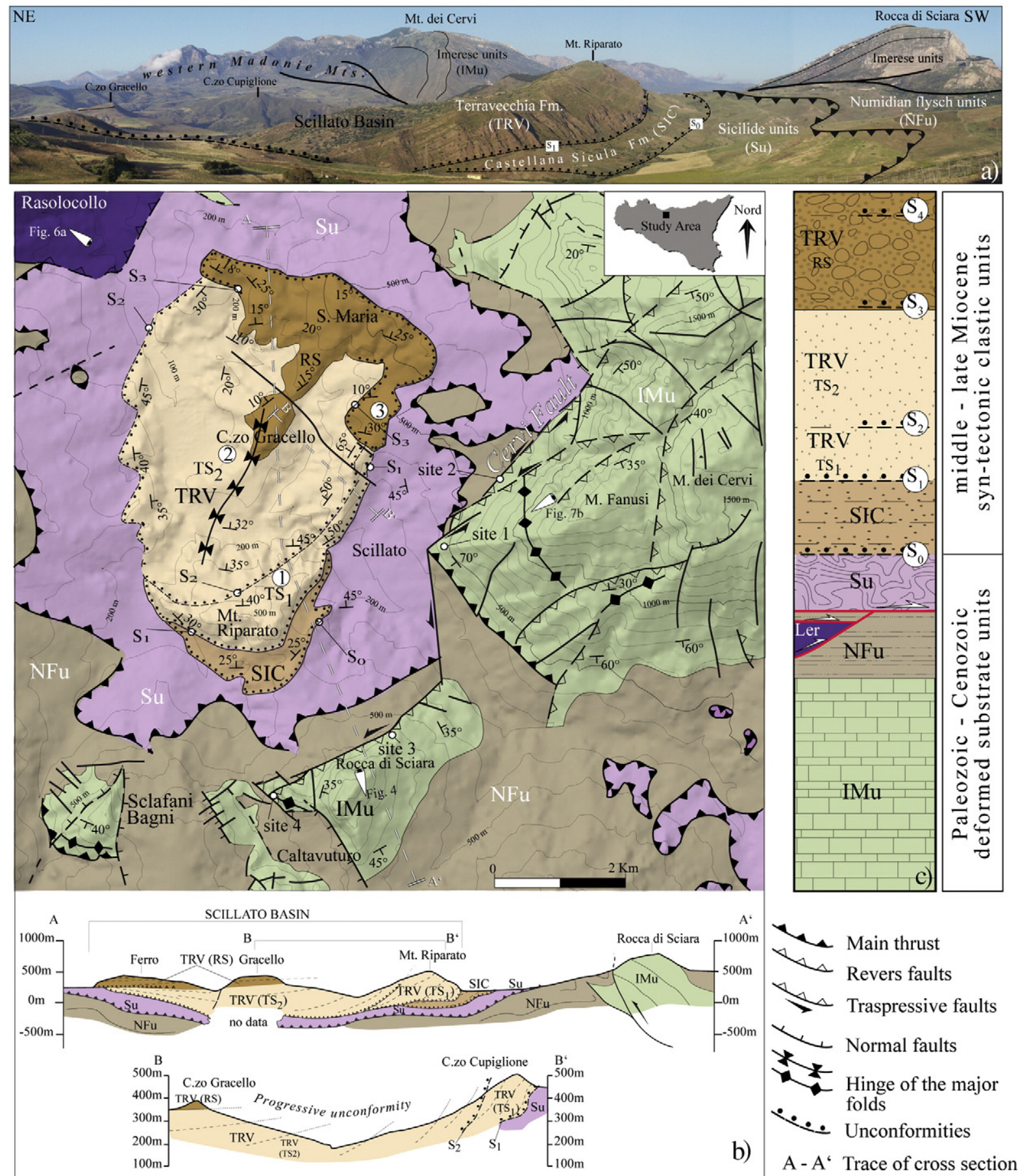

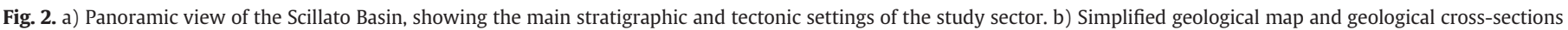

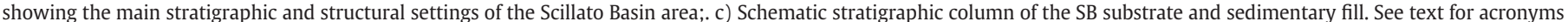
relatable to main tectonic units (IMu, NFu, Ler and $\mathrm{Su}$ ), clastic covers (SIC and TRV) and main unconformities $\left(\mathrm{S}_{0}, \mathrm{~S}_{1}, \mathrm{~S}_{2}, \mathrm{~S}_{3}\right.$ and $\left.\mathrm{S}_{4}\right)$.

Pleistocene (according with Roure et al., 2002). Detailed field data was collected during mapping related to the recent development of the CARG Project (CARtografia Geologica Project of the Italian National Geological Survey, Geological Sheet "Termini Imerese", Catalano et al., 2011a); this data, supported by interpretation of deep seismic reflection profiles crossing the study area (SI.RI. PRO. line, Accaino et al., 2010), shows that the tectonic wedge in this sector is made up of a set of imbricated tectonic units, buried beneath the Neogene-Quaternary sedimentary covers or outcropping in correspondence of major structural highs. From bottom to top (Fig. 2c), a tectonic wedge can be recognized, consisting of: (a) imbricated thrust sheets of Meso-Cenozoic slope-to-basin carbonates and radiolarites with interbedded carbonate breccias (Imerese units, IMu) and covered by upper Oligocene-lower Miocene argillites and turbiditic quarzarenites (Numidian flysch units, $\mathrm{NFu}$ ); (b) a tectonic body made up of Permian to Triassic rocks (Lercara complex, Ler) locally outcropping north-westward from the SB; (c) upper Oligocene-lower Miocene deposits (Numidian flysch) detached from their Imerese substrate, overthrusting the Lercara complex; (d) Cretaceous-Oligocene varicolored clays, limestones and tuffitic marlstones (Sicilide units, Su) overthrusting Numidian flysch units (during the Langhian to Serravallian time interval). Deep seismic data in this sector (Accaino et al., 2010; Catalano et al., 2011b) shows 
the IMu units ovethrusting a thick tectonic wedge made up of carbonate platform unit imbricates, in their turn representing the lowermost structural level (Fig. 1c). The IMu outcrop in correspondence of the main structural highs which surround the SB (Monte dei Cervi and Rocca di Sciara).

\section{The Scillato Basin succession}

The above-described deformed substrate units are unconformably overlain by an (up to) $1300 \mathrm{~m}$ thick middle-upper Miocene silici-clastic sedimentary succession that can be subdivided into two main lithostratigraphic units: (1) the Catellana Sicula Fm. (SIC) and (2) the Terravecchia Fm. (TRV), respectively, bounded by regionally recognized angular unconformities (Figs. 2c and 3).

\subsection{Castellana Sicula Fm.-SIC}

This is an informal unit (see Lo Cicero et al., 1997 and Catalano et al., 2000) consisting of up to $50 \mathrm{~m}$ thickness of emipelagic clays, siltstones, gravity flow sandstones and conglomerates deposited in an outer, shelf-to-slope setting. Analysis of the microfossil assemblage (both planktonic foraminifers and calcareous nannofossils) revealed an upper Serravallian to lower Tortonian relative age for this formation (Catalano et al., 2011a). The Castellana Sicula Fm. locally crops out at the southern edge of the SB (Fig. 4) where it overlies unconformably (unconformity $\mathrm{S}_{0}$ ) the deformed substrate units (Fig. 2). Previous authors (Catalano and D'Argenio, 1990; Catalano et al., 2002; Gugliotta, 2010, 2011) interpreted the Castellana Sicula Fm. as the remnant of submerged thrust-top basin in fill. These basins originally developed, from the late Serravallian, in the "outer" wedge-top depozone (Gugliotta, 2012) and were subsequently deformed and involved in the advancing thrust belt after the earliest Tortonian. Since the late Tortonian, due to sub-aerial exposition, fluvial incision and intense erosion, most of the sedimentary fill of these basins has been removed, producing a rather unconstrained stratigraphic gap. For these reasons, the Castellana Sicula Fm., which initiates the Scillato Basin succession, will not be taken into consideration here in the tectono-depositional evolution of the Scillato Basin. It will be used only to better define the base of the upper Tortonian succession, which represents the true aim of this paper.

\subsection{Terravecchia Fm.-TRV}

The Terravecchia Fm. outcrops widely in the study area as an (up to) 1250 m-thick succession of conglomerates, sandstones and clays (Catalano and D'Argenio, 1990; Abate et al., 1993, 1996, 1999; Butler and Grasso, 1993; Giunta et al., 2000; Gugliotta, 2010; Catalano et al., 2011a) representing the main bulk of the Scillato Basin succession. At the base, the Terravecchia Fm. unconformably rests on an erosional angular unconformity $\left(S_{1}\right.$, Fig. 2). The latter is well exposed along the southern and south-eastern margins of the basin (Monte Riparato) where it appears as a northward dipping, well-inclined ( $40^{\circ}$ up to $50^{\circ}$ ) surface, cutting both the Castellana Sicula Fm. and the deformed substrate units (Sicilide units) (Figs. 2 and 4a). Detailed sampling and dating of the microfossil assemblage (both planktonic foraminifers and calcareous nannofossils) revealed a relative upper Tortonian age for the Terravecchia Fm. (Gugliotta, 2010; Catalano et al., 2011a). No rocks of lower Messinian age are present in the succession studied, contrary to documentation by previous authors (e.g. Abate et al., 1999). The Terravecchia Fm. filling the SB has been deeply investigated from a stratigraphic, sedimentologic and structural point of view by several authors (Catalano and D'Argenio, 1990; Grasso and Butler, 1991; Abate et al., 1993, 1996, 1999; Butler and Grasso, 1993; Alliez et al., 1996; Guarnieri, 1998, 2004; Del Ben and Guarnieri, 2000; Giunta et al., 2000; Gugliotta and Agate, 2010). The most important conclusions are reported in Table 1.

\section{The upper Tortonian succession of the Scillato Basin}

Revised and fresh, more detailed stratigraphic and sedimentologic data collected in the upper Tortonian Terravecchia Fm. (Gugliotta, 2010, 2012; Gugliotta and Agate, 2010), with regard to this formation, highlighted a complex depositional framework consisting of six main facies associations, which are: gravelly braidplain (A), floodplain with ephemeral ponds (B), sandy-gravelly river-dominated delta front (C), brackish prodelta clayey siltstones (D), prograding delta slopes conglomerates and sandstones (E) and delta top conglomerates and sandstones ( $F$ ). These facies associations (described below) define two main stages in the SB evolution consisting of (Fig. 3a) an early "transgressive" fining-upward-sequence (TS) and a later "regressive" coarsening-upward-sequence $(R S)$. A slightly too strong a geometric discordance (locally with erosional features) can be traced between the TS and RS deposits.

\subsection{Transgressive sequence, TS}

The TS characterizes the southern, central and western portions of the SB (Figs. $2 \mathrm{~b}$ and 3). There it onlaps the already emplaced chain units, along the southern and south-western edge of the SB. The TS consists of two major rock bodies, here named $\mathrm{TS}_{1}$ and $\mathrm{TS}_{2}$ respectively (Fig. 2c).

\subsection{1. $\mathrm{TS}_{1}$ deposits}

The $\mathrm{TS}_{1}$ is a composite unit made up of a basal edge of crudely amalgamated conglomerate beds pertaining to the facies association $A$, overlain in turn by a clayey rock body pertaining to the facies association B (Fig. 3).

More specifically, facies association A is characterized by an (up to) 200 m-thick stack of amalgamated to unamalgamated beds (each up to $10 \mathrm{~m}$ thick) of red conglomerates and sandstones. The bulk of the conglomerate is represented by poorly sorted, pebble-to-boulder-size (and often "out-size"-up to $1.5 \mathrm{~m}$ ), well-rounded clasts. Imbrications, inverse to normal gradation are also often observable. Pebble cluster structures (Dal Cin, 1968) and large-scale erosional scours are often visible in the conglomerate beds, while the sandy beds show large-scale cross-bedding (mostly through-cross type) and/or horizontal planar lamination (Fig. 4a,b,c). This facies association is here interpreted as a gravelly braided fluvial system (following Miall, 1977, 1978, 1985; Rust, 1978; De Celles et al., 1991). Moving upward, facies association A gradually passes into an (up to) approximately $100 \mathrm{~m}$ thick darkish-to-pinkish clays and siltstones with interbedded, roughly lens-shaped, beds of conglomerates and sandstones (facies association B); here this is related to a floodplain with wide overbank areas and isolated channels (Fig. 4d).

The $\mathrm{TS}_{1}$ records a mainly SE-directed, roughly unidirectional palaeoflow (Fig. 5a), suggesting a source area location toward the north. Analysis of the mean clast composition reveals an extrabasinal supply for the conglomerates whose clasts reflect the composition of the surrounding substrate (prevalently Su and NFu) with a conspicuous presence of metamorphic and igneous fragments derived from the Sardinia and Kabilo-Calabride crystalline bedrock (see also Ferla and Alaimo, 1975; Catalano and D'Argenio, 1990; Cirrincione et al., 1995). The conspicuous presence of crystalline bedrock-derived clasts supports a northward located source area.

\subsection{2. $\mathrm{TS}_{2}$ deposits}

Moving upwards in the succession and (northward) toward the basin center, the $\mathrm{TS}_{1}$ rapidly wedges out unconformably overlain by the $\mathrm{TS}_{2}$ across the unconformity $\mathrm{S}_{2}$. The latter is a slightly erosional surface, which can be traced in the central-southern Scillato Basin and which spreads out laterally (along the western Scillato Basin) cutting the deformed substrate units while also blanketing the older $\mathrm{S}_{1}$ (Fig. 3). The $\mathrm{TS}_{2}$ consists of two main facies associations arranged to form the retrograding part of a small flood-dominated delta in 


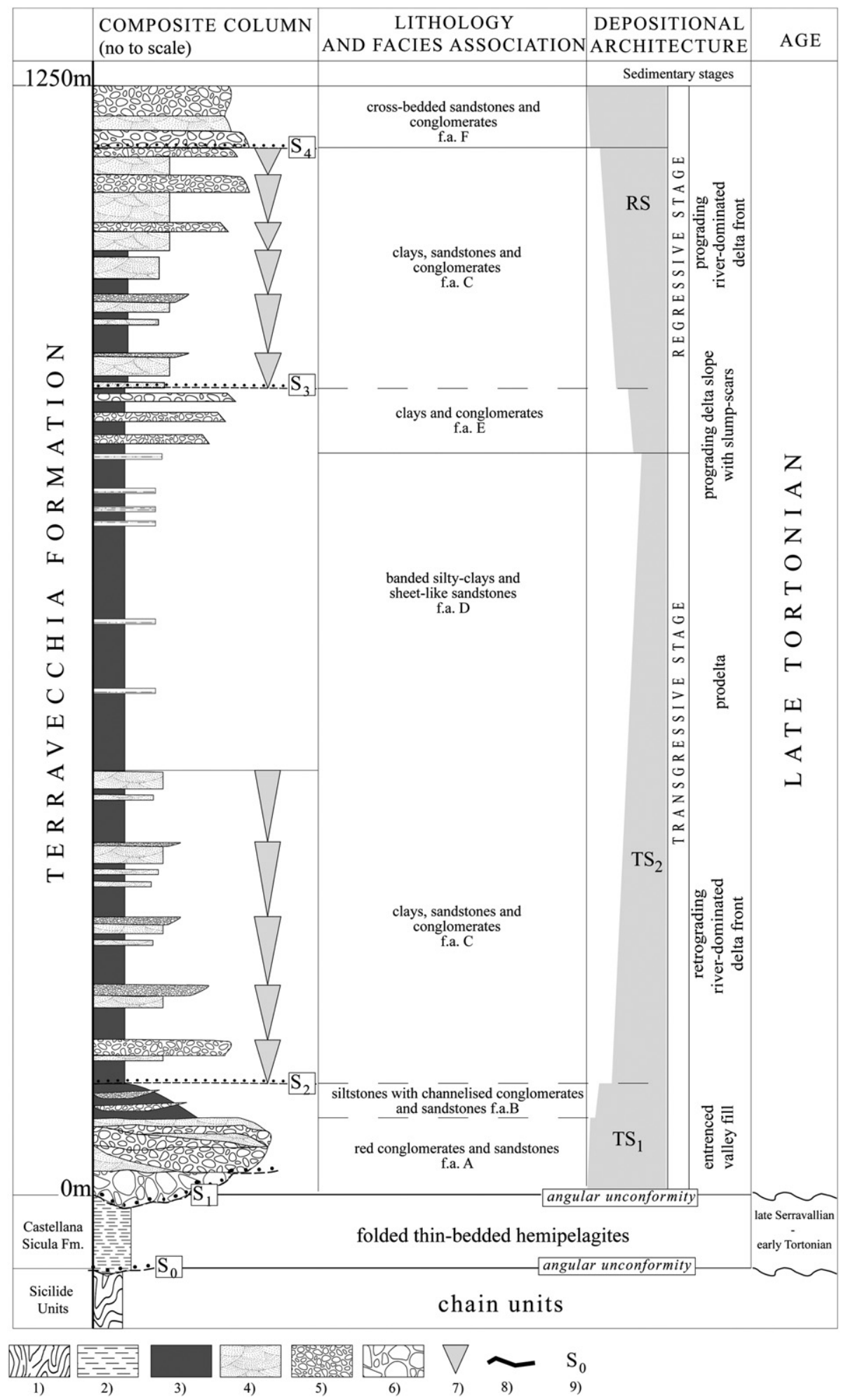

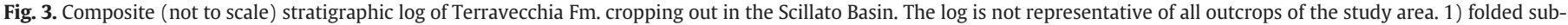

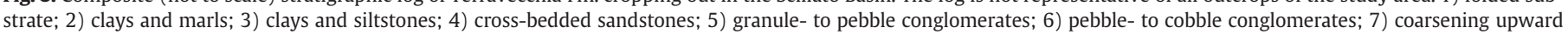
sequences; 8) major erosive surface; 9) major unconformities. See also text for acronyms.

which a delta front (facies association $C$ ) and a prodelta (facies association $D$ ) can be distinguished. The facies association $C$ is characterized by up to $350 \mathrm{~m}$ thick interbedded siltstones, cross-bedded and often rippled sandstones and conglomerates arranged vertically, forming delta front sequences that are decametric in scale, shallowing and coarsening upwards (Fig. 4e). The delta front sequences are superimposed, at basin scale, with a thinning upward "backstepping" trend, merging laterally and upwardly with the facies association D (Fig. 4f). Facies association $\mathrm{C}$ associated with a sandy-gravelly river-dominated delta front environment (Galloway, 1975), developing in the submerged distal part of small fan delta lobes under a microtidal regime. This facies association could also be interpreted as recording the deposition of flood-generated delta front sandstone lobes developed as part of a small fan delta system (Mutti et al., 2000, 2003). 

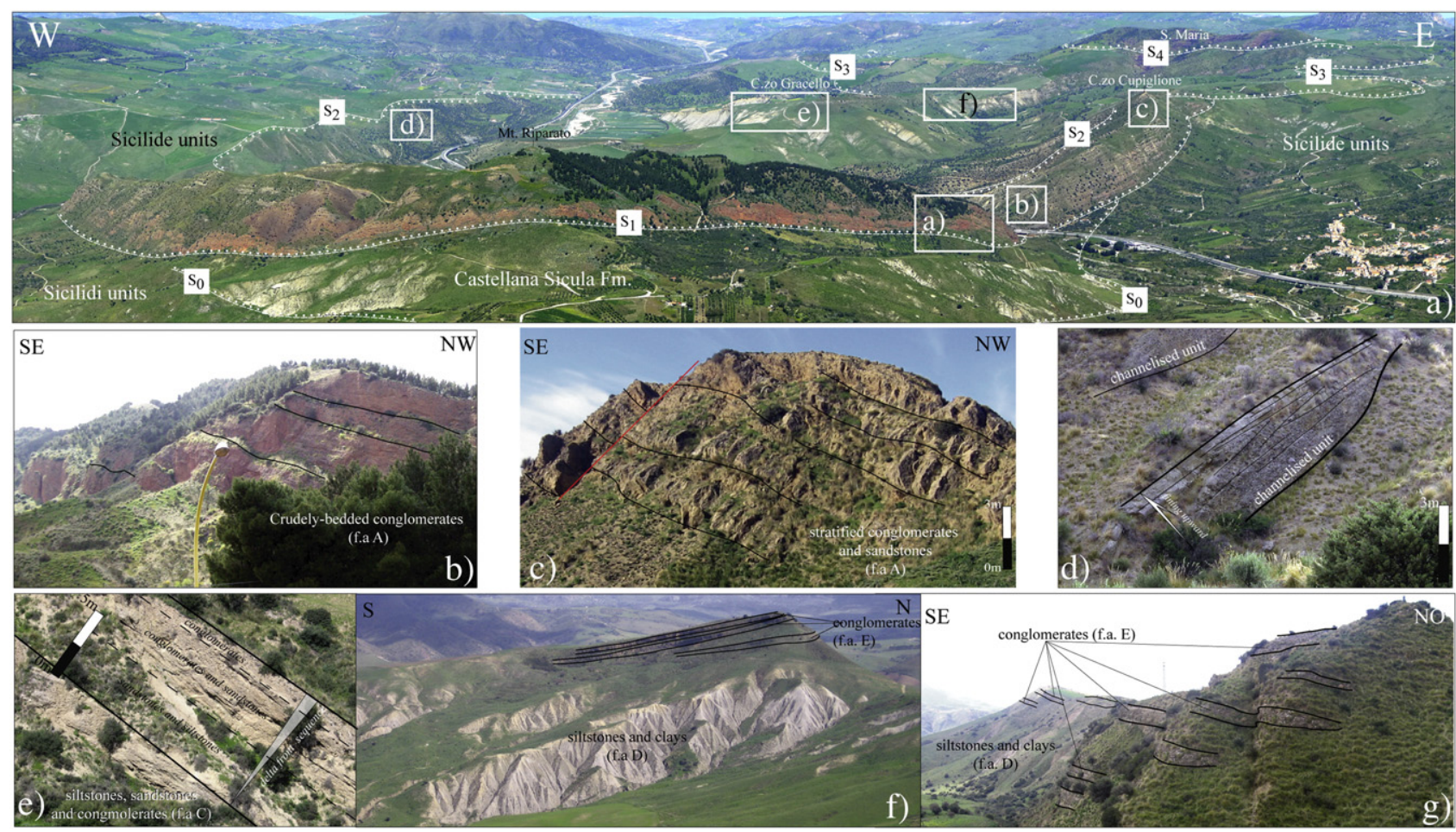

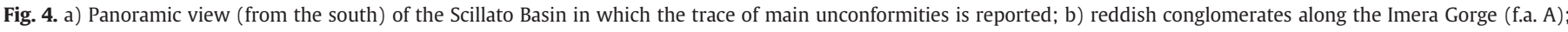

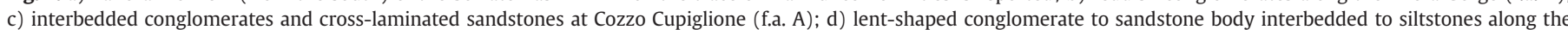

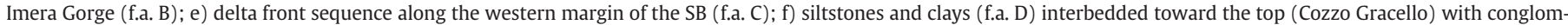
erate bodies (f.a. E); g) conglomerates interbedded to siltstones and sandstones (f.a. E).

Facies association D is characterized by (up to) 450 m-thick light blue/grayish-to-brownish siltites and clayey-siltites with brackish fauna, locally interbedded with centimeter-thick sheet-like sandstones. Facies association $\mathrm{D}$ has been associated with a distal delta front passing into brackish prodelta. This interpretation is supported by the scarcity of burrowing, by the presence of typical brackish ostrachods (Crimi, 1987) and by the oligotypic assemblage of foraminifers. The prodelatic deposits (facies association D) gradually coarsen upsection due to the progressive interbbedding with upward-thickening sandstones and conglomerates showing the incoming transition to the RS. Analyses of palaeocurrents reveal that the $\mathrm{TS}_{2}$ deposits recorded a sudden change in palaeoflow when compared to those pertaining to the $\mathrm{TS}_{1}$. The dispersal pattern (in facies association $\mathrm{C}$ ) is characterized by a roughly radial shape, ranging from N- to NW-ward-directed (between N270 and N340) and locally SW-ward-directed palaeoflows (Fig. 5b). Thus, a new source area might have developed SE-ward from the basin providing the clastic material for the deltaic apparatus.

\subsection{Regressive sequence, $R S$}

The RS consists of a thinner rock body than the TS, and characterizes the central-eastern, eastern and north-eastern areas of the SB (Figs. 2 and 3). In its lowermost part (around Cozzo Gracello), the RS develops with up to $\sim 100 \mathrm{~m}$ of yellowish silt-clays interbedded with tabular- to slightly lenticular conglomerate bodies (each up to 5 m-thick) and sandstones (Figs. 3 and $4 \mathrm{~g}$ ). Mass-flow-related structures such as large clay chips, normal gradation and load casts are

Table 1

Table resuming the main conclusions addressed by previous authors for the Scillato Basin stratigraphy and structural setting.

\begin{tabular}{|c|c|c|c|c|}
\hline Authors & Structural and geodynamic setting & $\begin{array}{l}\text { Arrangement of the basin fill } \\
\text { (Teravecchia Fm.) }\end{array}$ & Age & Original basin geometry \\
\hline $\begin{array}{l}\text { Catalano and } \\
\text { D'Argenio (1990) }\end{array}$ & Piggyback basin-contractional setting & $\begin{array}{l}\text { Fining- to slightly coarsening upward } \\
\text { sedimentary cycle }\end{array}$ & Late Tortonian & $\mathrm{N}-\mathrm{S}$ trending \\
\hline $\begin{array}{l}\text { Butler and } \\
\text { Grasso (1993) }\end{array}$ & Perched basin-contractional setting & $\begin{array}{l}\text { Fining upward incised valley to estuarine } \\
\text { to marine sedimentary cycle }\end{array}$ & Tortonian & $\mathrm{N}-\mathrm{S}$ trending \\
\hline Abate et al. (1999) & $\begin{array}{l}\text { Intramontane basin-post-orogenic } \\
\text { extension }\end{array}$ & $\begin{array}{l}\text { Fining upward sedimentary cycle } \\
\text { developed through three main stages }\end{array}$ & Late Tortonian - early Messinian & $\mathrm{N}-\mathrm{S}$ trending \\
\hline $\begin{array}{l}\text { Del Ben and } \\
\text { Guarnieri (2000) }\end{array}$ & Hangingwall basin-contractional setting & No data & Late Tortonian - early Messinian & No data \\
\hline Giunta et al. (2000) & $\begin{array}{l}\text { Extensional setting,--negative inversion } \\
\text { of already emplaced thrusts }\end{array}$ & $\begin{array}{l}\text { Two sedimentary cycles, respectively } \\
\text { fining upward (the older) and coarsening } \\
\text { upward the younger }\end{array}$ & Late Tortonian - early Messinian & $\mathrm{N}-\mathrm{S}$ trending \\
\hline This paper & $\begin{array}{l}\text { Wedge-top basin deformed by } \\
\text { syn-depositional transpression }\end{array}$ & $\begin{array}{l}\text { Fining- to coarsening upward sedimentary } \\
\text { cycle developed } \\
\text { through an early trangressive and a } \\
\text { late regressive stage }\end{array}$ & Late to latest Tortonian & $\begin{array}{l}\text { The N-S-geometry resulting } \\
\text { from interference pattern }\end{array}$ \\
\hline
\end{tabular}




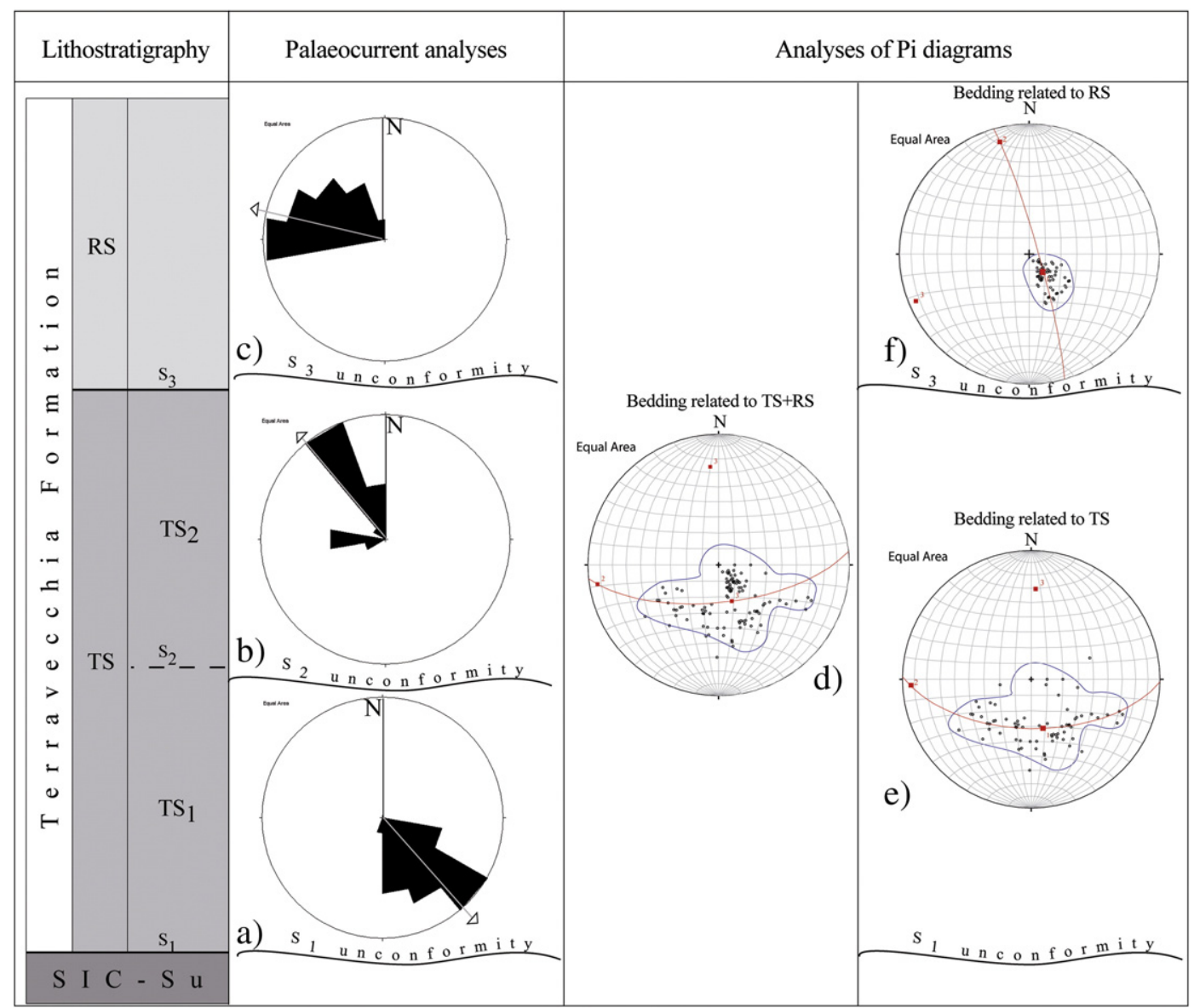

Fig. 5. Explanation of the data relative to the bedding analyses and palaeocurrent analyses performed in the Terravecchia Fm. filling the SB.

common in the conglomerate beds (facies association E). Microscopic analyses carried out in the clayey interbeddings revealed a poorly preserved, shallow-marine, very late Tortonian microfossil assemblage. This facies association has been interpreted (Gugliotta and Agate, 2010) as deposited in a prograding and tectonically "steepened" delta slope setting. On the other hand, Abate et al. (1999) have assigned the Cozzo Gracello conglomerates to a younger (Messinian age) sedimentary cycle. Upsection and laterally toward the east and the north, the thickness of clay interbeds rapidly decreases and they are replaced by sandstones (Fig. 3) again marking the transition to facies association $C$. In this stratigraphic position the latter facies association is characterized by amalgamated, coarsening and upward-thickening delta front sequences. The sequences are arranged in an aggradational to slightly progradational stacking pattern and are interpreted (Gugliotta and Agate, 2010) as a prograding river-dominated delta front. The rock body characterized by prograding delta front sequences (facies association $\mathrm{C}$ ) is bounded by the erosional unconformity $S_{3}$ at the base, and is unconformably covered $\left(\mathrm{S}_{4}\right.$ at $\mathrm{S}$. Maria area, Figs. 2 and 3 ) by gravelly, delta-top conglomerates and cross-stratified sandstones (facies association F) outcropping along the northern and north-eastern margins of the basin. The $S_{3}$ unconformity, in particular, develops with erosional features along the eastern and north-eastern margins of the basin, where it cuts the deformed substrate units. Moving westward and north-westward the $S_{3}$ also cuts the already deformed TS deposits (as well as $S_{1}$ and $S_{2}$ ) showing an intraformational unconformity which gradually disappears toward the basin center. Analyses of palaeocurrents performed in the RS deposits, above the $S_{3}$ (facies association $C$ ), show that a strong new variation in palaeodrainage occurred during the RS deposition. The data collected in these deposits accounts for a mean W-to WNW-directed palaeoflow showing a slightly radial dispersal pattern (Fig. 5c). The preliminary analysis of the mean clasts composition, characterizing the rocks deposited during this stage, highlights the increasing presence of Meso-Cenozoic IMu-derived rock-types widely outcropping in the Scillato Basin surroundings (e.g. Monte dei Cervi) also with a supposed intrabasinal-intraformational component of the coarse clastics composition. The above-mentioned data might suggest that both a further shifting, toward the E and NE, of source areas and a probable "cannibalistic" erosion of lifted sectors of the basin may have occurred during the RS deposition.

\subsection{Analysis of Pi diagrams}

The projection of the pole-to-bedding data collected at several measurement sites located in different sectors of the basin, defines a best-fit point (Allmendinger, 2002) relatable to a major syncline $\mathrm{N}-\mathrm{S}$-trending. However, the distribution of poles to bedding suggests that this structure is not compatible with a single plicative trend but could be relatable to two main superimposed, folding trends (Fig. 5d). The occurrence of a local geometric discordance between TS and RS deposits allowed us to perform a differential analysis of strata separating the data collected in these two sequences.

Specifically, the distribution of poles to bedding in the TS deposits (Fig. 5e) appears compatible with that observed for the main syncline (TS + RS in Fig. 5d). Otherwise, the distribution of pole to bedding resulting from the RS deposits (Fig. 5f) shows a different pattern 

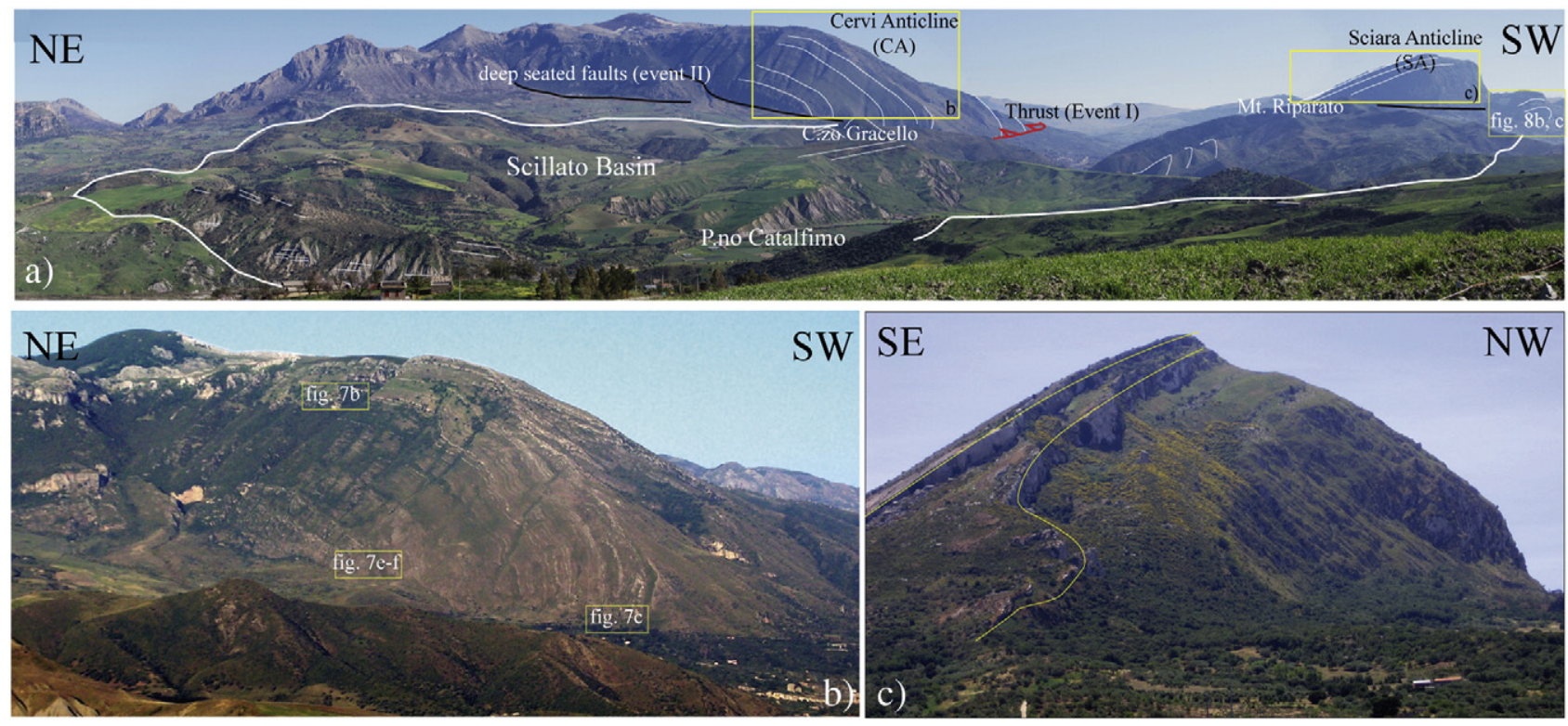

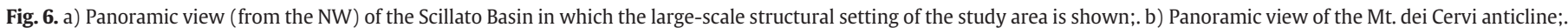
c) Panoramic view of the Rocca di Sciara structural high.

pertaining to a gently NW-dipping monoclinal structure. This data suggests that TS and RS recorded a different deformative pattern, allowing us to infer that the RS stage deposits have not recorded the folding related to Event I.

\section{Major structures in the IMu}

The detailed field data integrated with previous studies (Grasso et al., 1978; Abate et al., 1982, 1988; Bigi et al., 1991), allowed us to interpret the Monte dei Cervi and Rocca di Sciara ridges as partially outcropping, NW-SE-trending ramp anticlines (H1 fold system) involving Meso-Cenozoic rocks (Imerese units and their covers). These anticlines are here named Cervi Anticline (CA) and Rocca di Sciara Anticline $(R A)$ respectively. Field and subsurface data also indicates that the CA overthrusts toward the south-west on the RA (Figs. 2 and 6).

\subsection{Field structural setting}

A complete set of new structural data has been collected along the limbs of the major anticlines (CA and RA; site 1 in Figs. 2 and 7a) consisting of both minor folds $(h)$ and cleavage-extensional vein systems $(C-J)$.

\subsubsection{Cervi anticline, $C A$}

Along the south-western slope of the Monte dei Cervi two minor fold-systems were recognized and named, respectively $h 1$ and $h 2$.

h1 system consists of $143 / 12^{\circ}$ hinge-oriented minor folds, showing flank and axial-plane geometries compatible with drag fold developed along the forelimb of the major CA (Fig. 7c,h). A $142 / 25^{\circ}$ oriented crenulations lineation (sensu Davis and Raynolds, 1996) is also present along the flanks of these minor folds (Fig. $7 \mathrm{~g}$ ). The $h 1$ fold system is compatible with an ENE-WSW-oriented maximum palaeo-stress $(\sigma 1)$. h2 system consists of $047 / 09^{\circ}$ hinge-oriented minor folds, compatible with a NW-SE-oriented maximum palaeo-stress ( $\sigma 1)$.

The mesostructural analyses also revealed the existence of two main cleavage-extensional vein systems ( $C-J$; Fig. $7 \mathrm{~d}, \mathrm{~h})$ named $C_{1}-J_{1}$ and $C_{2}-J_{2}$, respectively.

$C_{1}-J_{1}$ system consists of $058 / 80^{\circ}$-oriented pressure solution cleavage associated with $328 / 75^{\circ}$ extensional veins;

$C_{2}-J_{2}$ system consists of $338 / 75^{\circ}$-oriented pressure solution cleavage and associated $070 / 27^{\circ}$ extensional veins.

The orientations of the $C_{1}-J_{1}$ system is compatible with an ENE-

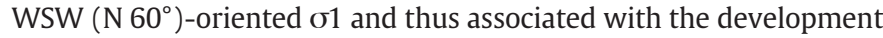
of the $h 1$ fold system while, the orientations of the $C_{2}-J_{2}$ system is compatible with a NNW-SSE (N $340^{\circ}$ )-oriented $\sigma 1$ and thus associated with the development of the $\mathrm{h} 2$ fold system. Cross-cutting relationships suggest that $C_{1}-J_{1}$ system is older than $C_{2}-J_{2}$ systems (Fig. $7 \mathrm{~d}, \mathrm{~h}$ ) and thus, $h 1$ is older than $h 2$.

Interpretation of structural data suggests that the $\mathrm{h} 1$ fold system includes minor folds of the major $\left(H_{1}\right)$ NW-SE-trending CA developed during the compressional Event I. The CA, in its turn, is re-folded along a more recent ENE-WSW plicative trend represented by the h2 system and here considered as having developed during the compressional Event II. Other evidence of superposition of tectonic structures of a different age are suggested by the large-scale setting of CA. The major NW-SE-trending anticline shows a clearly observable SE-dipping axis, which, moving north-westward, is cut and displaced by a superimposed NE-SW-striking, SE-dipping major transpressive, left-lateral faults system here included in the Cervi Fault (site 2 in Figs. 2 and 7a,b,e,f). The statistical analysis of the striated fault planes revealed that the transpressional faults were generated under a maximum horizontal palaeo-stress, oriented as those

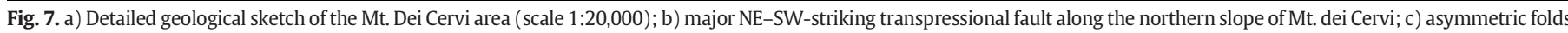

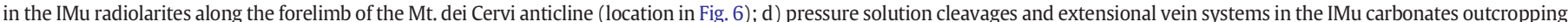

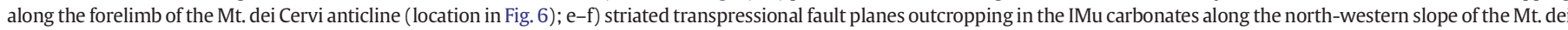

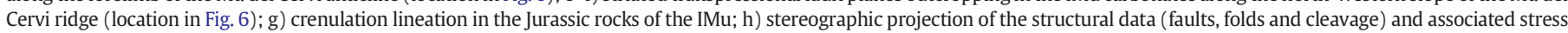
axes calculated from stress inversion applied to transpressive faults and slickenlines, collected along the CA. Data from Salvini (2001). 

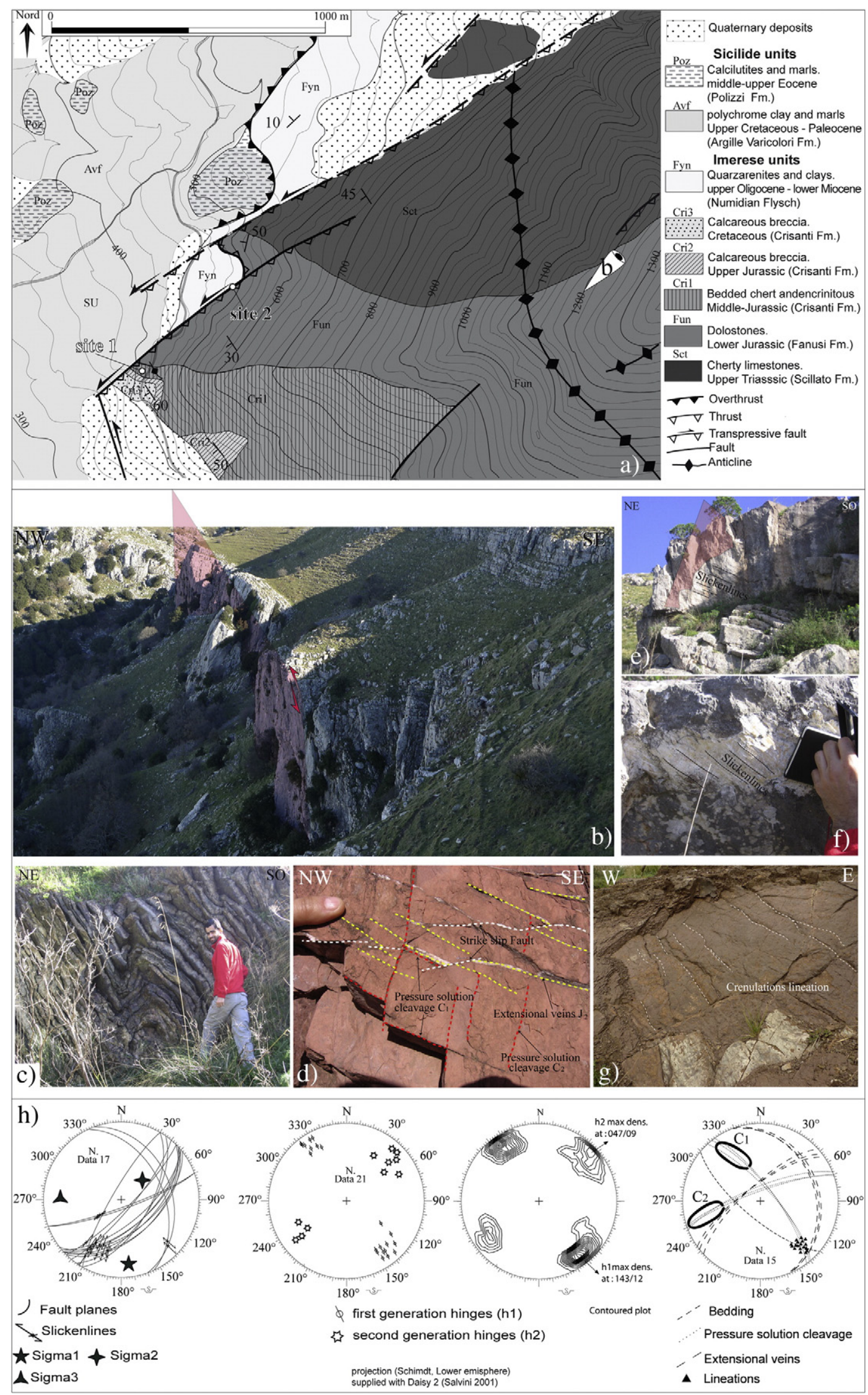
reconstructed for the h2 folds nucleation. The stress field orientation is consistent with those calculated elsewhere, along the Kumeta Fault (see Fig. 1b for location), where it is associated with the deep-seated Event II (Avellone et al., 2010).

\subsubsection{Rocca di Sciara anticline, $R A$}

Minor and major SW-ward verging recumbent folds, showing $\mathrm{NW}$-SE-trending hinge ( $\mathrm{N} 320^{\circ}, \mathrm{h} 1$ fold system) have also been recognized along the major RA (Figs. 6 and 8a). The latter is markedly dissected by more recent high-angle faults (Fig. 8a). Data collected in the site 3 (Figs. 2 and 8a) is compatible with SSE-dipping, high-angle (about $70^{\circ}$ ) faults showing SE-dipping slickenline with an approximate $15^{\circ}$ to $45^{\circ}$ rake (Fig. $8 \mathrm{c}, \mathrm{d}, \mathrm{e}$ ). The calcite fibers are compatible with a left-lateral transpressive movement. Analysis of kinematic indicators allowed us to constrain the palaeo-stress field as compatible with an approximately $\mathrm{N} 350^{\circ}$-oriented and near-to-horizontal (about $\left.12^{\circ}\right) \sigma 1$, associated with an approximate $\mathrm{N} 045^{\circ}$-oriented, high-angle, $\sigma_{2}$ (about $45^{\circ}$, Fig. $8 \mathrm{f}$ ).

\subsection{Sub-surface structural setting}

Knowledge about the deep sub-surface structural setting of the study sector of the Sicilian thrust belt and adjacent regions derives from the interpretation of the borehole-calibrated seismic profiles (Catalano et al., 2000, 2011b; Accaino et al., 2010; Albanese and Sulli, 2011). In the study portion of the chain, the northern part of the SIRIPRO seismic profile allows imaging, based on seismic facies characters and borehole calibration, the thicker part of the orogenic building consisting of (from top to bottom): Numidian flysch and Sicilidi nappes, Meso-Cenozoic deep-water carbonates (Imerese and Sicanian thrust units) that overthrust thick shallow-water carbonate imbricates. A preliminary geologic interpretation (Fig. 9, Catalano et al., 2011b) allowed us to image a shallow structural level consisting of a stack of northward-dipping imbricated thrust-sheets, involving the thin deep-water Meso-Cenozoic successions (Sicilide, Numidian and Imerese units) and emplaced during the shallow-seated compressional Event I. Clearly imaged by the profiles, the Imerese thrust-sheets subsequently appear folded and uplifted, generating north-verging structures (i.e. backthrusts), by activation of deep-seated, high-angle faults generated at a deeper structural level (Albanese and Sulli, 2011; Catalano et al., 2011b).

\section{Discussion}

\subsection{Syn-tectonic stratal pattern}

At the basin-scale, moving upsection in the Scillato Basin succession (from TS to RS) a progressive decrease in the mean tilting value of the strata (section B-B' in Figs. 2 and 10a,b) can be observed. An approximate $40^{\circ}$ discordance can be traced between the lower portion of the Terravecchia Fm. (about $70^{\circ}$ of strata attitude at Cozzo Cupiglione-Mt. Riparato) and its upper portion (about $15^{\circ}$ of strata attitude at Cozzo Gracello). This peculiar feature accounts for a partially preserved growth offlap (Fig. 10c, Ford et al., 1997) coherent with the development of a progressive unconformity (Riba, 1976; Hardy and Poblet, 1995; Ford et al., 1997). The growth geometry suggests the N- and NW-ward tiltings of the eastern and south-eastern limbs of the basin, plausibly in response to the progressive lifting of the deformed substrate units.

Beyond the growth offlap geometry, several intraformational unconformities $\left(S_{2}, S_{3}, S_{4}\right)$ are present within the Scillato Basin succession.
The geometrical and stratigraphic relationships associated with these surfaces suggest that they may represent syntectonic intraformational angular unconformities (sensu Riba, 1976) developed in response to local uplift and erosion of the basin margins. On a larger scale, these unconformities and the associated sedimentary wedges appear to have been "imbricated" (Fig. 10b) to form an assembled composite progressive unconformity (Fig. 10d, Anadon et al., 1986) imaging a mean $\mathrm{N}$ - to $\mathrm{NW}$-ward migration of the basin depocenter. In a tectonically active orogenic belt (such as the Sicilian belt), these structures have less potential for preservation as they are either involved in deformation or eroded, and thus often partially preserved. The growth geometry is also accompanied by a great variation in the thickness of the succession, moving from the center toward the eastern margin of the basin (Fig. 11). Specifically, the TS reaches up to $900 \mathrm{~m}$ at the basin center (around Cozzo Gracello) decreasing to $\sim 600 \mathrm{~m}$ along the southern and south-eastern margin of the basin. Moving toward the north-east the TS deposits decrease dramatically in thickness and disappear along the north-eastern and eastern limbs of the Scillato Basin (Fig. 11). There, the upper Tortonian succession consists only of approximately 300 m-thick RS deposits. Data emerging from analysis of Pi diagrams sustains the hypothesis that the deposition of the early TS and late RS occurred during active tectonics, which induced the syn-depositional deformation of the strata. The progressive shifting of clastic source areas (highlighted by palaeocurrent analyses) is also consistent with kinematic evolution. The relative age of the Terravecchia Fm. as constrained by biostratigraphic analysis, is latest Tortonian, thereby suggesting that the syn-tectonic deformation occurred during that time at least.

\subsection{Depositional evolution}

The depositional evolution of the Scillato Basin as recorded by the Terravecchia Fm. during the late Tortonian shows that sedimentation took place in a dynamic sedimentary basin that evolved through two main depositional stages. The transition from undersupplied (TS) to oversupplied conditions (RS) reflects profound changes in the basin fill dynamics mainly controlled by syn-depositional tectonics. The deposition of the older TS took place in a deepening depositional setting recording an increase in the creation of accommodation space over time (from confined braidplain to low energy alluvial plain passing into retrograding delta front and prodelta). The earliest $\mathrm{TS}_{1}$ is interpreted by considering the lithologic and facies characteristics as a floor lag deposited in a narrow morphostructural depression, approximately NW-SE-oriented, incised on the deformed substrate and probably enclosed between two major culminations of the deformed substrate units. It is tempting to consider this depression as a palaeovalley along which short and very steep, bed-load ephemeral streams drain a nearby source area (north-ward located) delivering coarse clastics toward a S-ward located marine area. This interpretation is sustained by lithology, sedimentary facies, mean palaeocurrents direction (SE-oriented, Fig. 5) and the conglomerate clast composition. Today only a small remnant of this sedimentary environment is preserved in the Scillato Basin, although part of it might be preserved locally southwards from the study area.

The transition from $\mathrm{TS}_{1}$ to the $\mathrm{TS}_{2}$ marks three major changes in the basin dynamics; (i) the basin was completely flooded and a rapid decrease in sediment grain size occurred; (ii) an inferred tilting of the original depositional surface occurred as suggested by the intraformational syntectonic angular unconformity $\left(\mathrm{S}_{2}\right)$; (iii) deposition of the $\mathrm{TS}_{2}$ is marked by a sudden (from approximately SE-directed to $\mathrm{N}$ - and NW-directed) inversion of palaeoflows (Fig. 5) accompanied

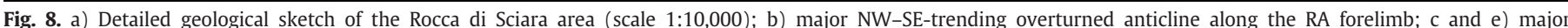

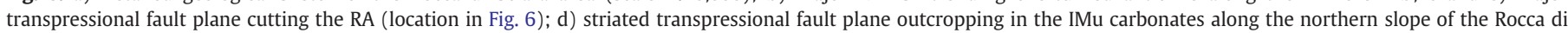

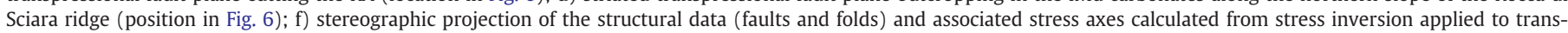
pressive faults and slickenlines, collected along the RA. 

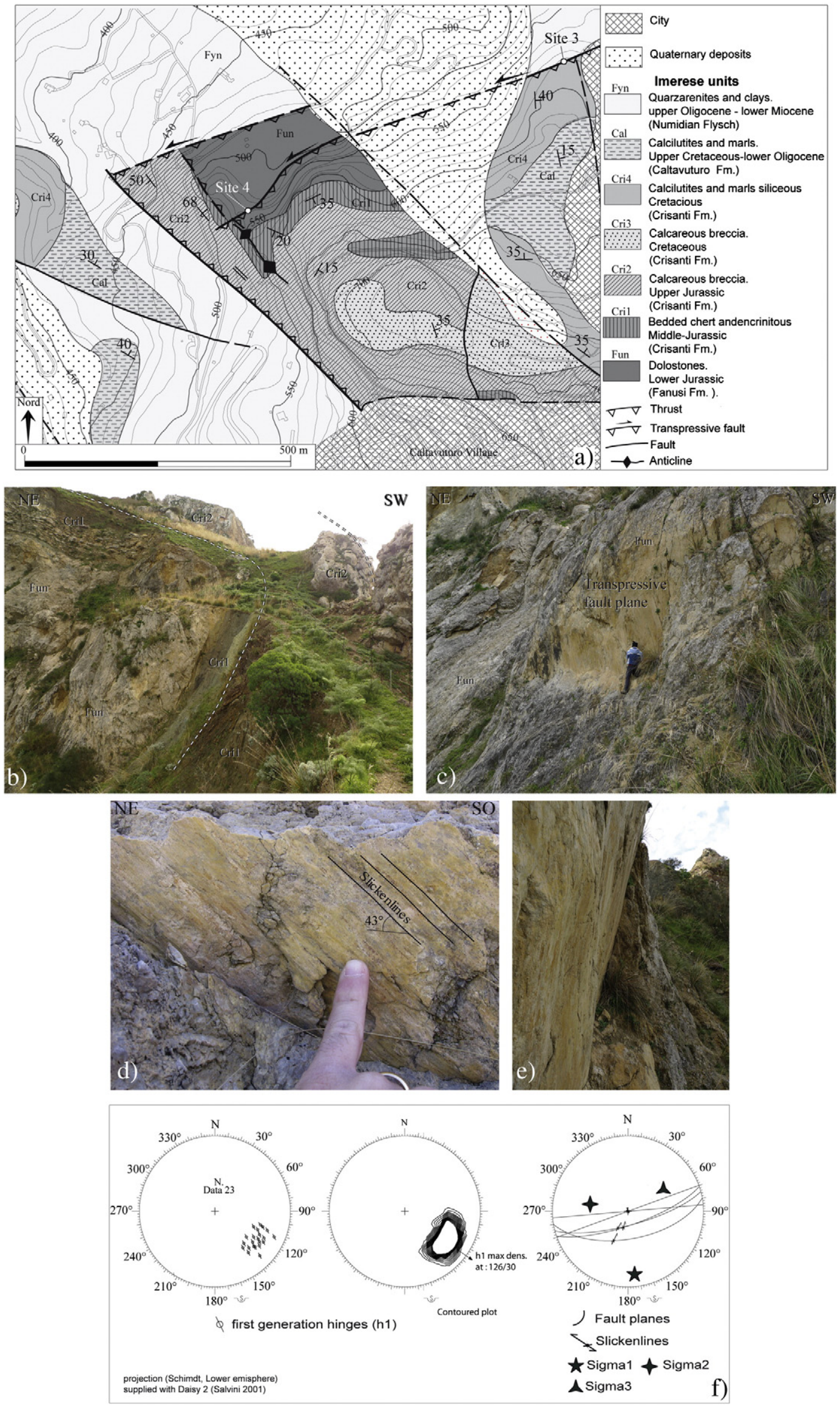


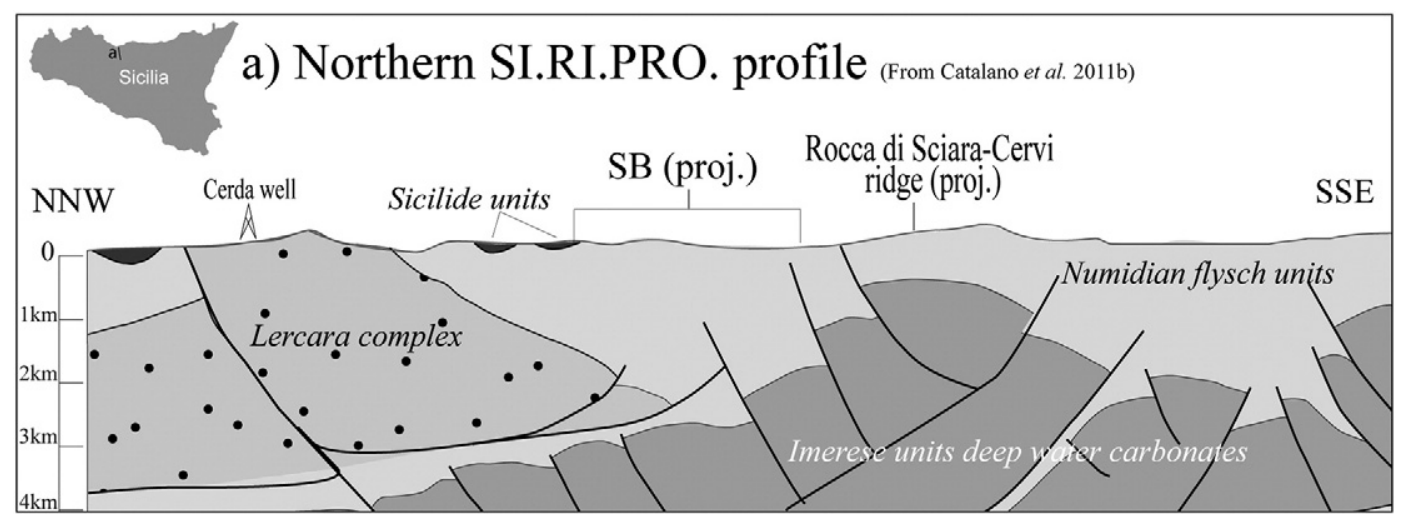

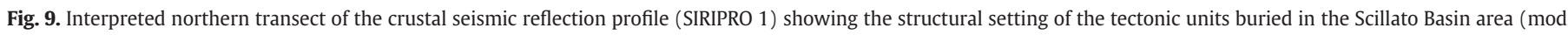
after Catalano et al., 2011b). Data from Salvini (2001).

by new source areas south-eastward from the present-day basin margin.

We might infer that the tilting of the depositional surface is relatable to incipient activity of the Cervi Fault, which caused the initial growth of localized structural highs southwards from the Scillato Basin. As a consequence the already existent depositional area filled by $\mathrm{TS}_{1}$ was folded and eroded and the Scillato Basin became isolated from the main marine area located toward the south. A new depositional setting developed, represented by the sedimentation of $\mathrm{TS}_{2}$ deltaic deposits. These small deltas were probably supplied from the south and the south-east, merging in their frontal part with sheltered, very shallow- brackish marine areas.

The onset of RS sedimentation records a sudden increase in the coarse-clastics supply to the marginal depositional systems. This increase has here been associated with an inferred enhancement of relief in the source areas, accompanied by rejuvenation of the streams that produced the oversupplying of the frontal portion of the small delta systems (accompanied by gravity instability of the delta slope) and their rapid progradation into the basin. During the RS deposition some important changes in the SB dynamics occurred. Firstly, an important intraformational, syntectonic, angular unconformity $\left(S_{3}\right)$, associated with considerable discordance and erosion at the eastern basin margin, is present within this sequence. This data indicates that a new and more important tilting of the depositional surface occurred. Moreover, the RS strata recorded a sudden new variation in the mean palaeoflows (WNW-directed), which confirmed the uplifting of some areas and a major shifting of the source area toward the east (Fig. 5).

\subsection{Tectono-sedimentary model}

All the data discussed in the previous section may refer to changes involving both the Scillato Basin and its substrate, which occurred during the deposition of the upper Tortonian Terravecchia Fm. In particular, these changes concerned: (1) the original Scillato Basin geometry; (2) tilting of the original basin margins; (3) uplift of local structural highs and (4) new source area creation (Fig. 12). A plausible scenario might imply that the Scillato Basin evolution was propelled by the incipient uplifting of the already emplaced deformed substrate units along high-angle transpressional faults (Fig. 12). As discussed previously in this paper, the Imerese units outcrop and form major structural highs, eastward and southward from the Scillato Basin (Mt. dei Cevi, Rocca di Sciara), where they are lifted up along a transpressional fault system (Cervi Fault).

The activation of the transpressional structures, during the late Tortonian, could explain syn-sedimentary tectonics recognized throughout the Terravecchia Fm. and previously discussed in the paper. Subsequent transpressional structures also probably produced the rising of the Learcara complex deposits, at present exposed along the Rasolocollo structural high (north-westward from the SB, see Fig. 2b).
For a clearer explanation of the Scillato Basin evolution, it would be more important to consider the different deformative patterns recorded by TS and RS and the resulting interference pattern represented by the present-day $\mathrm{N}-\mathrm{S}$-oriented major syncline. This peculiar aspect allowed us to infer that the Scillato Basin recorded a polyphase tectonic evolution, during which an original, NW-SE-oriented depression (probably part of an original wedge-top basin related to compressional Event I) was non-coaxially deformed by a superimposed NNW-SSE-oriented stress field during the compressional/transpressional Event II (Fig. 12). Thus, the present-day N-S orientation of the Scillato Basin does not correspond to the original basin geometry but resulted from large-scale interference between two deformative patterns. Therefore, in the study area, the upper Tortonian Terravecchia Fm. may have recorded deformations developed at different structural levels during the transition between the shallow-seated (Event I) and the deep-seated compressional-transpressional event (Event II, Fig. 13a).

Comparing field and sub-surface data the tectono-sedimentary evolution of the Scillato Basin is here interpreted as induced by activation of deep-seated faults (Figs. 9 and 13). The transpressional fault system (Cervi Fault) outcropping in surrounding SB regions (Mt. dei Cervi and Rocca di Sciara) is here correlated with deep-seated structures enucleated in deeper structural levels and which have moved upward into shallower levels during Event II (Fig. 13a). Thus, it can be inferred that the deep-seated deformation, during the late Tortonian, was propagated upwards into the shallower structural level and sedimentary covers controlling the location, geometry and evolution of local syn-tectonic basin as suggested by both structural and depositional interferences (Fig. 13b).

The data presented here also suggests that during the late Miocene the study sector of the Sicilian thrust belt was characterized by a mainly contractional-transpressional tectonic regime not consistent with a late Tortonian back-arc-related extension or with the orogenic gravitational collapse models previously invoked by some Authors (Giunta et al., 2000). This aspect has been recently discussed using regional comparisons, in the paper by Gugliotta (2012). In this paper, the late Miocene Sicilian foreland basin system (sensu De Celles and Giles, 1996) is characterized by a wedge-top depozone split into an "inner" sector (containing the Scillato Basin, among others), in which sedimentary basins are strongly affected by localized transpression since the very late Tortonian at the least, and an "outer" sector characterized by wider basins whose sedimentary infill was still slightly affected by compressional deformation.

Our conclusions are supported and comparable with data presented elsewhere for certain syn-tectonic basins in the Appenines and other neighboring orogens (e.g. Bonini et al., 1999; Bonini and Sani, 2000; Alçiçek and ten Veen, 2008; Onofrio et al., 2009). Particularly interesting is the comparison with the work by Alçiçek and ten Veen (2008) in the Tauride Belt (SW Turkey) in which the authors discuss the early late Miocene evolution of the Acipayam piggy-back basin and the underlying Lycian nappe. The authors suggested that 

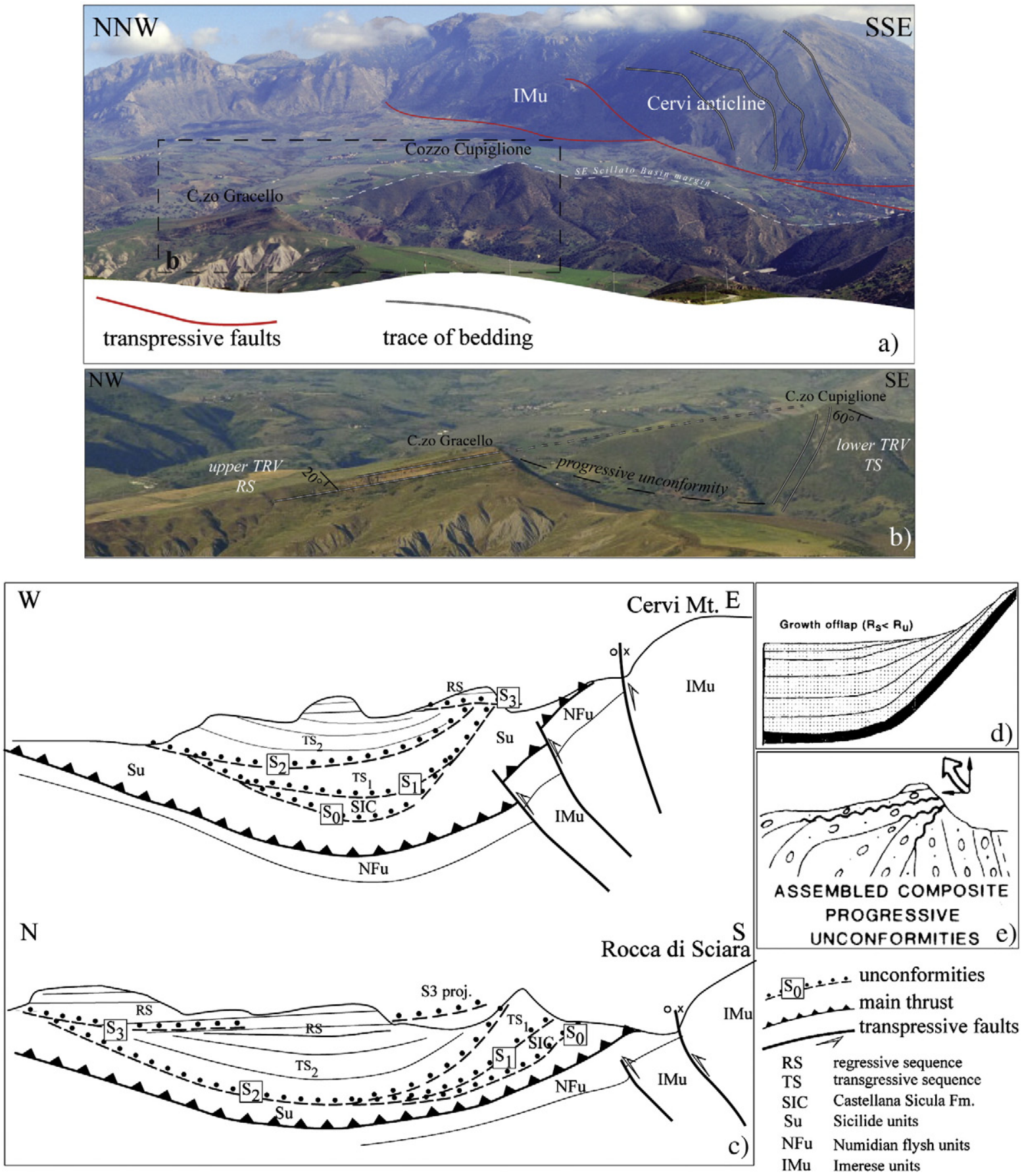

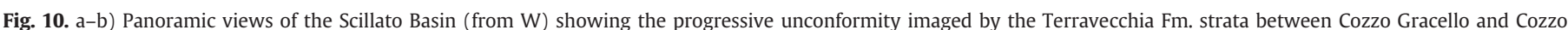

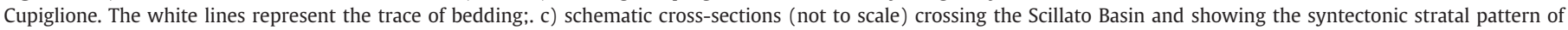

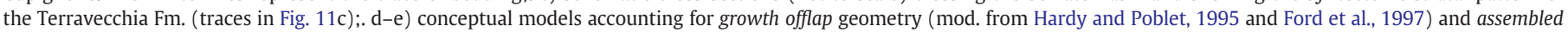
composite progressive unconformity (mod. from Anadon et al., 1986).

thick-skinned thrusting reactivated early extensional faults in the autochthon and may explain the evolution of "piggyback" basins located at the core of large open folds. The tectono-sedimentary evolution of these basins is strongly dependent on their position compared to the hinge of the large fold (Fig. 8 in Alçiçek and ten Veen, 2008). In the Sicilian thrust belt, deep-seated structures may have reactivated Mesozoic extensional faults in the lowermost carbonate platform units (Catalano and D'Argenio, 1978; Avellone et al., 2010), and been propagated upward producing a regional-scale folding into the upper structural levels similar to those described in the Tauride Belt (Fig. 13). Nevertheless, in contrast to the model proposed by Alçiçek and ten Veen (2008) the late Miocene Sicilian wedge-top basins, located above and to the side of these culminations, recorded mainly transpressional or compressional tectonics.

\section{Concluding remarks}

- The depositional evolution of the Scillato Basin, as recorded by the upper Tortonian Terravecchia Fm. suggests that sedimentation took place in a dynamic sedimentary basin, which evolved through two successive depositional stages, here named transgressive stage TS and regressive stage RS, respectively.

- The transition between TS and RS was driven by the incipient uplifting, eastward and southward from the Scillato Basin, of already 

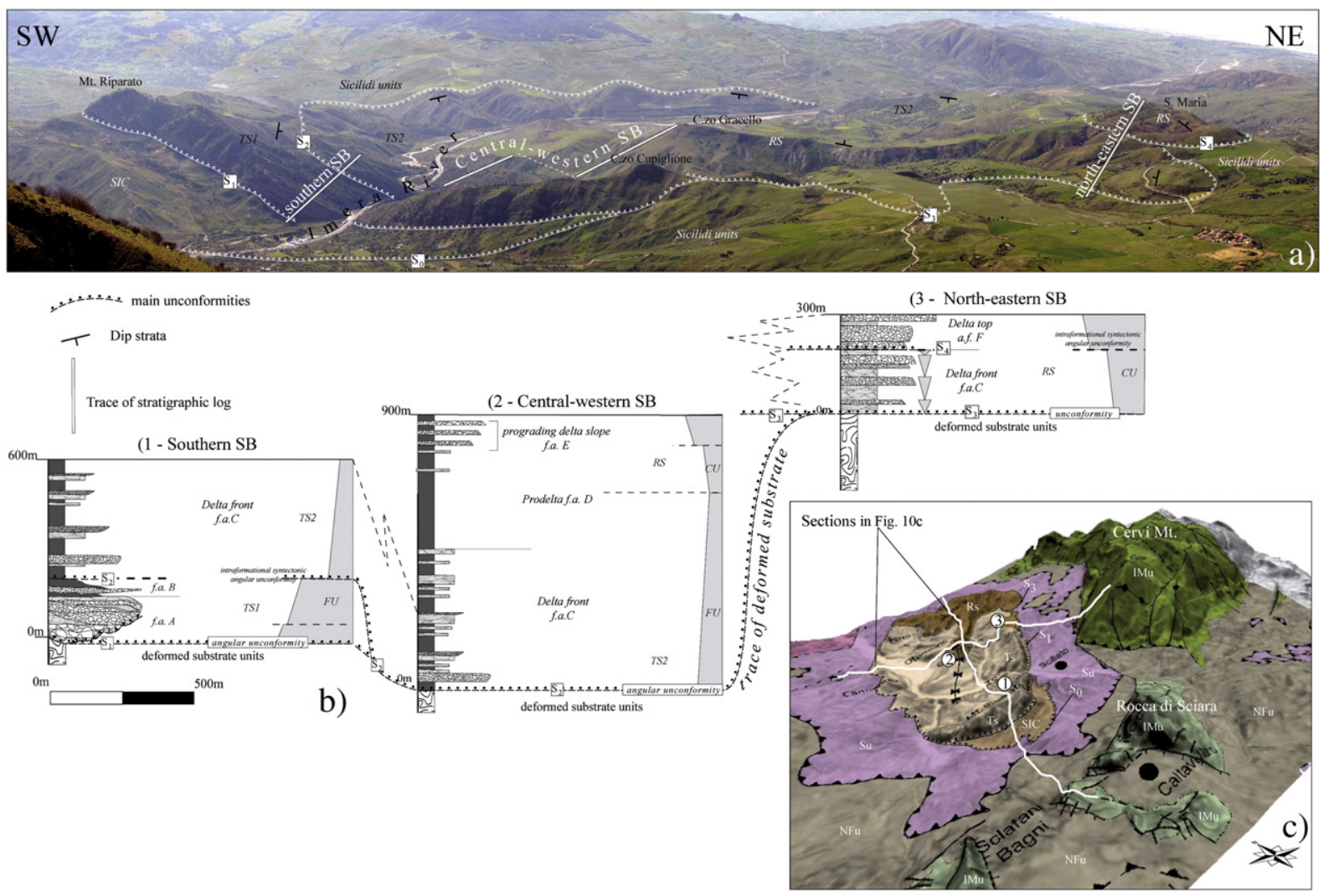

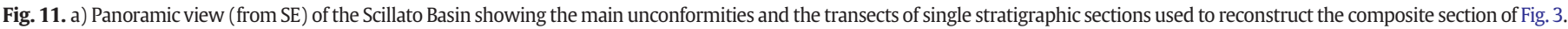
(b) Stratigraphic logs (not to scale) showing the variation in thickness and depositional arrangement of the Terravecchia Fm. in the SB; c) 3D geological map of the Scillato Basin area.
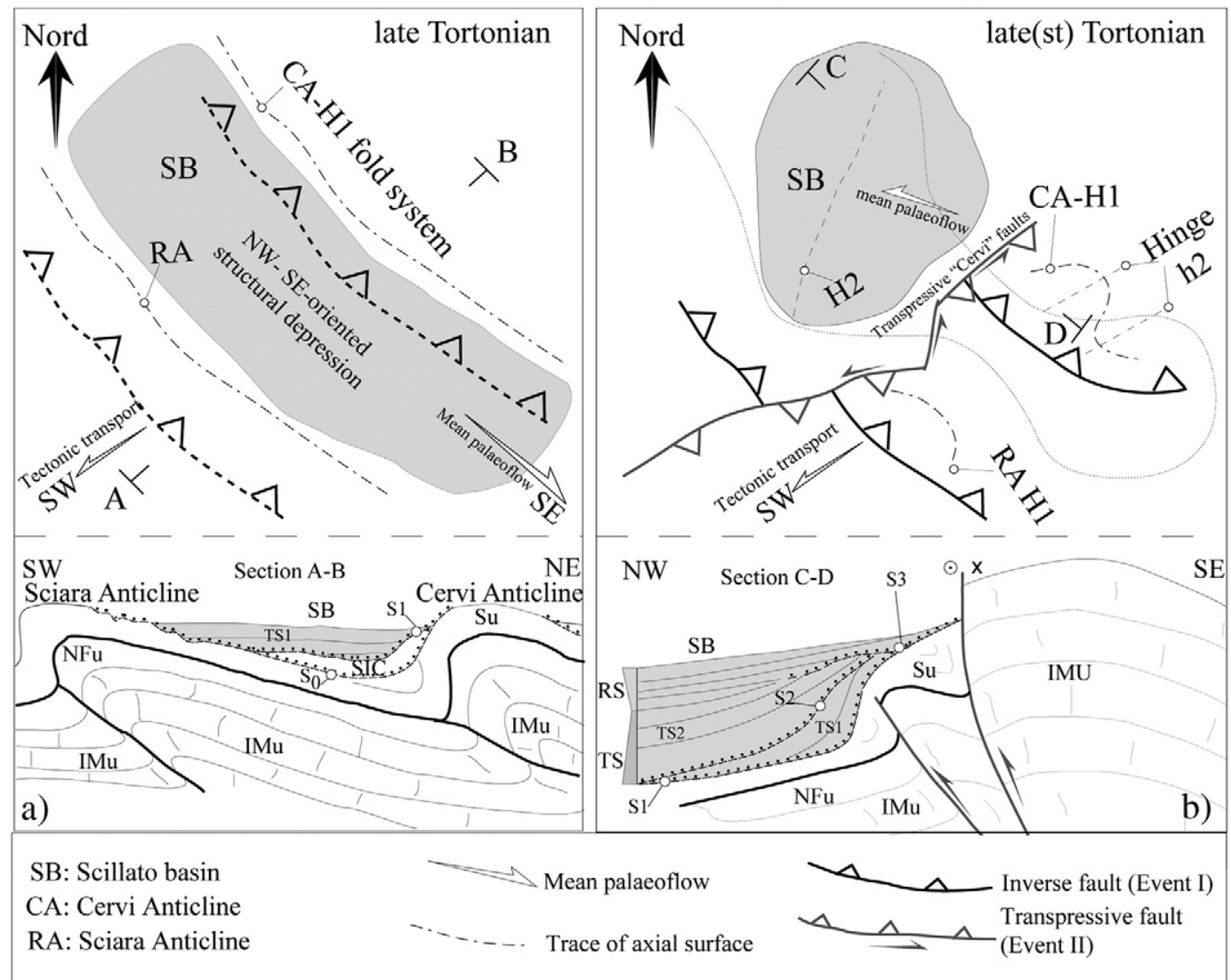

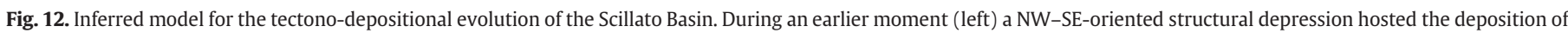
the $\mathrm{TS}_{1}$. Later (right) the original depression has been deformed by the transpressional faults and the deposition of $\mathrm{TS}_{2}$ (p.p.) and RS took place. 


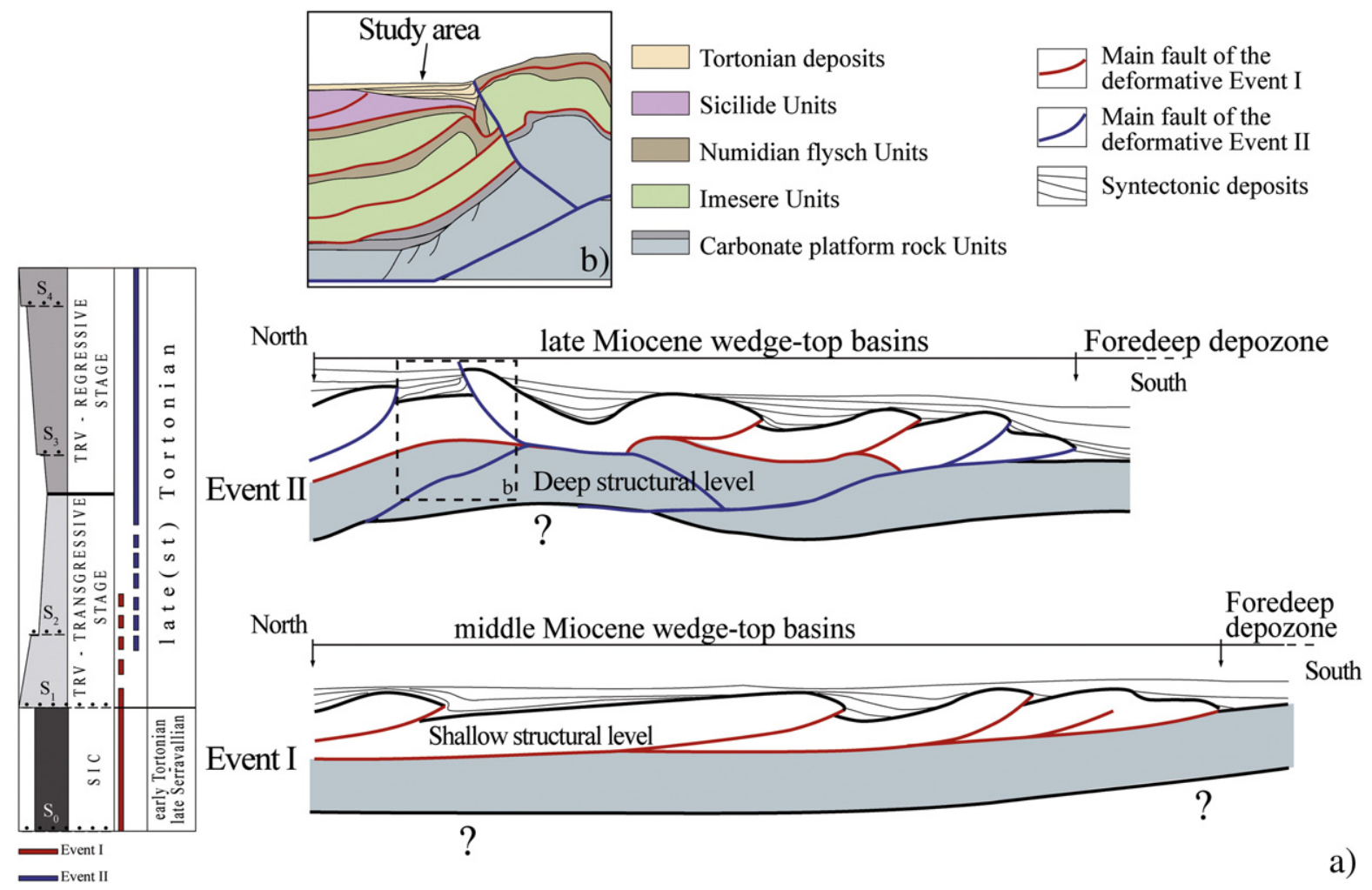

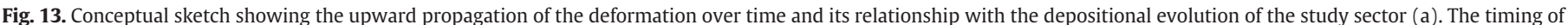
the transition between the Events I and II is also shown as inferred in the study area (b).

emplaced substrate units along high-angle, mainly SE-dipping transpressional faults (here included in the major Cervi Fault).

- The present-day N-S orientation of the Scillato Basin does not correspond to the original basin geometry but has resulted from the large-scale interference between two, non coaxial, deformative events developed at different structural levels.

- The Scillato Basin fill recorded a polyphase tectonic evolution during which an original, NW-SE-oriented structural depression (related to the Event I major compressional structures) was non-coaxially deformed by a superimposed, mainly SE-ward-dipping, deep-seated, transpressive fault developed during the Event II.

- Existence of a wide range of evidence of syn-depositional tectonics in the Terravecchia Fm. filling the Scillato Basin, suggests that the deep-seated transpressional structures were active during the late (st) Tortonian at the least.

- In this sector of the Sicilian thrust belt, deep-seated deformation was propagated upwards into the shallower structural level and sedimentary covers controlling the location, geometry and tectono-sedimentary evolution of wedge-top basins.

\section{Acknowledgment}

The Editor G.J. Weltje, Marco Bonini and two anonymous reviewers are warmly acknowledged for their helpful reviews and constructive comments. The paper also benefited from useful suggestions and stimulating discussion with Raimondo Catalano, Attilio Sulli, Mauro Agate and Massimilano Barchi.

\section{References}

Abate, B., Catalano, R., D'argenio, B., Di Stefano, P., Renda, P., 1982. Carta geologica delle Madonie orientali. Istituto di Geologia Università di Palermo.

Abate, B., Pescatore, T., Renda, P., Tramutoli, M., 1988. Schema Geologico Dei Monti Di Termini Imerese E Delle Madonie Occidentali. Memorie della Società Geologica Italiana 41, 465-474.
Abate, B., Incandela, A., Renda, P., Slaczka, A., 1993. Depositional processes of the Terravecchia deposits (miocene) near Scillato (Sicily). Inter. Ass. Sedim. 14tf Reg. Meeting Sediment. Marrakesh, April 27-29.

Abate, B., Incandela, A., Renda, P., Slaczka, A., 1996. Transition from river to lacustrine deposits, post-tectonic basin analysis (Terravecchia Formation, Sicily, Italy). 30th Intern. Geol. Congress, Beijing, China, 4-14 August. Abstract, 1: 267.

Abate, B., Incandela, A., Renda, P., Slaczka, A., 1999. Depositonal processes of the Terravecchia Formation deposits (Miocene) near Scillato (Sicily). Annales Societatis Geologorum Poloniae 69, 27-48.

Accaino, F., Catalano, R., Di Marzo, L., Giustiniani, M., Tinivella, U., Nicolich, R., Sulli, A., Valenti, V., Manetti, P., 2010. A crustal seismic profile across Sicily. Tectonophysics, http://dx.doi.org/10.1016/j.tecto.2010.07.011.

Albanese, C., Sulli, A., 2011. Backthrusts and passive roof duplexes in fold-and-thrust belts. Tectonophysics, http://dx.doi.org/10.1016/j.tecto.2011.11.002.

Alçiçek, M.C., ten Veen, J.H., 2008. The late Early Miocene Acıpayam piggy back basin: refining the last stages of Lycian nappe emplacement in SW Turkey. Sedimentary Geology 208, 101-113.

Alliez, J.M., Imbert, P., Faugeres, J.C., Duee, G., Wallez, M.J., 1996. The Neogene Scillato Basin, north Sicily: interaction between sedimentation and tectonics. Riunione del Gruppo di Sedimentologia del CNR. Catania, 10-14 Ottobre 1996.

Allmendinger, R.W., 2002. StereoWin for Windows v.1.2.0 (free software). Department of Earth and Atmospheric Sciences. Cornell University, Ithaca, NY.

Amodio-Morelli, L., Bonardi, G., Colonna, V., Dietrich, D., Giunta, G., Ippolito, F., Liguori, V., Lorenzoni, S., Paglionico, A., Perrone, V., Piccarreta, G., Russo, M., Scandone, P., Zanetti-Lorenzoni, E., Zuppetta, A., 1976. L'Arco Calabro-Peloritano nell'orogene appenninico-maghrebide. Memorie della Società Geologica Italiana 17, 1-60.

Anadon, P., Cabrera, L., Colombo, F., Marzo, M., Riba, O., 1986. Syntectonic intraformational unconformities in alluvial fan deposits, eastern Ebro Basin margins (NE Spain). International Association of Sedimentologists, Special Publications 8, 259-271.

Argnani, A., 1989. The Gela nappe: evidence of accretionary melange in the Maghrebian foredeep of Sicily. Memorie della Società Geologica Italiana 38, 419-428.

Avellone, G., Barchi, M., 2003. Le pieghe minori nelle unità imeresi e trapanesi dei Monti di Palermo ed il loro significato nell'evoluzione tettonica dell'area. Bollettino della Società Geologica Italiana 122, 277-294.

Avellone, G., Barchi, M.R., Catalano, R., Gasparo Morticelli, M., Sulli, A., 2010. Interference between shallow and deep-seated structures in the Sicilian fold and thrust belt, Italy. Journal of the Geological Society of London 167.

Bally, A.W., Gordy, P.L., Stewart, G.A., 1966. Structure, seismic data and orogenic evolution of Southern Canadian Rocky Mountains. Bulletin of Canadian Petroleum Geology 14, 337-381.

Bello, M., Franchino, A., Merlini, S., 2000. Structural model of Eastern Sicily. Memorie della Società Geologica Italiana 55, 61-70.

Bellon, H., Coulon, C., Edel, J., 1977. Le déplacement de la Sardaigne: synthèse de données géochronologiques, magmatiques et paleomagnetiques. Bulletin de la Societe Geologique de France 19, 825-831. 
Bianchi, F., Carbone, S., Grasso, M., Invernizzi, G., Lentini, F., Longaretti, G., Merlini, S. Moscardini, F., 1989. Sicilia orientale: profilo geologico Nebrodi-Iblei. Memorie della Società Geologica Italiana 38, 429-458.

Bigi G., Cosentino D., Parotto M., Sartori R. e Scandone P., (1991). Structural model of Italy. Scala 1:500.000. CNR-PFG.

Bonardi, G., De Capoa, P., Di Staso, A., Estevez, A., Martin-Martin, M., Martin, Rojas I., Perrone, V., Tent-Manclus, J.E., 2003. Oligocene-to-Early Miocene depositional and structural evolution of the Calabria-Peloritani Arc southern terrain (Italy) and geodynamic correlations with the Spain Betic and Morocco Rif. Geodinamica Acta 16, 149-169.

Bonini, M., Sani, F., 2000. Pliocene-Quaternary transpressional evolution of the AnziCalvello and northern S. Arcangelo basins (Basilicata, southern Apennines, Italy) as a consequence of deep-seated fault reactivation. Marine and Petroleum Geology 17, 909-927.

Bonini, M., Moratti, G., Sani, F., 1999. Evolution and depocentre migration in thrust-top basins: inferences from the Messinian Velona Basin (Northern Apennines, Italy). Tectonophysics 304, 95-108.

Boyer, S.E., Elliott, D., 1982. Thrust systems. AAPG Bulletin 66, 1196-1230.

Butler, R., Grasso, M., 1993. Tectonic controls on base-level variations and depositional sequences within thrust-top and foredeep basins: examples from the Neogene thrust belt of central Sicily. Basin Research 5, 137-151.

Caputo, M., Panza, G.F., Postpischl, D., 1970. Deep structure of the Mediterranean basin. Journal of Geophysical Researches 75 (26), 4919-4923.

Catalano, R., D'argenio, B., 1978. An essay of palinspastic restoration across the western Sicily. Geologica Romana 17, 145-159.

Catalano, R., D'argenio, B., 1982. Schema Geologico Della Sicilia Occidentale. In: Catalano, R., D'argenio, B. (Eds.), Guida Alla Geologia Della Sicilia Occidentale. Guide Geologiche Regionali: Mem. Soc. Geol. It., Suppl. A, 24, pp. 9-41. Palermo.

Catalano, R., D'Argenio, B. (Eds.), 1990. Hammering a seismic section: Guide book of the field trip in Western Sicily, International Conference "Geology of the Oceans". Terrasini (PA), May 17-19.

Catalano, R., Renda, P., Slaczka, A., 1978. Redeposited gypsum in the evaporitic sequence of the Ciminna basin, Sicily. In: Catalano, R., Ruggieri, G., Sprovieri, R. (Eds.), Messinian evaporites in the Mediterranean: Mem. Soc. Geol. It., 16, pp. 83-93. $6 \mathrm{ff}$.

Catalano, R., D'argenio, B., Torelli, L., 1989. From Sardinia Channel to Sicily straits. A geologic section based on seismic and field data. In: Boriani, et al. (Ed.), The Lithosphere in Italy: Advance in Earth Science Research, pp. 109-127.

Catalano, R., Di Stefano, P., Sulli, A., Vitale, F.P., 1996. Paleogeography and structure of the Central Mediterranean: Sicily and its offshore area. Tectonophysics 260, 291-323.

Catalano, R., Franchino, A., Merlini, S., Sulli, A., 2000. Central western Sicily structural setting interpreted from seismic reflection profiles. Memorie della Società Geologica Italiana 55, 5-16.

Catalano, R., Merlini, S., Sulli, A., 2002. The structure of western Sicily, central Mediterranean. Petroleum Geoscienze 8, 7-18.

Catalano, R., Sulli, A., Valenti, V., Albanese, C., Gasparo Morticelli, M., (and the DGG Working Group), Accaino, F., (and the OGS Working Group), Nicolich, R., Manzella, A., (and the IGG Working Group), Naselli, G., (and the CRES Working Group), 2010. The SI.RI.PRO. project: an integrated approach to Sicily geodynaminc setting. The geological interpretation of the Sicily crustal seismic line. Convegno nazionale GNGTS Prato 26-28 ottobre 2010. pp. 562-565.

Catalano R., Avellone G., Basilone L., Contino A., Agate M. et al., (2011a). Note illustrative della Carta Geologica d'Italia alla scala 1:50.000 dei fogli 609-596 "Termin Imerese - Capo Plaia", con allegata carta geologica in scala 1:50.000. ISPRA, Servizio Geologico d'Italia.

Catalano, R., Agate, M., Avellone, G., Basilone, L., Gasparo Morticelli, M., Gugliotta, C., Sulli, A., Valenti, V., Gibilaro, C., Pierini, S., 2011b. Walking along a crustal profile across the Sicily Fold and Thrust Belt. AAPG International Conference and Exhibition. Post Conference Field Trip Guide. ISBN: 978-88-97559-02-3.

Channell, J.E.T., Catalano, R., D'argenio, B., 1980. Palaeomagnetism and deformation of the Mesozoic continental margin in Sicily. Tectonophysics 61, 391-407.

Channell, J.E.T., Oldow, J., Catalano, R., D'argenio, B., 1990. Palaeomagnetically determined rotations in the western Sicilian fold and thrust belt. Tectonics 9 (4), 641-660.

Cirrincione, R., Grasso, M., Torelli, L., Attori, P., Mazzoleni, P., 1995. The porphyritic clasts of the tortonian conglomerates of north-central Sicily: palaeogeographic and palaeotectonic implications. Bollettino della Società Geologica Italiana 114.

Crimi, P., 1987. Per una conoscenza dei problemi dell'assetto del territorio. VI Congresso Nazionale dell'Ordine dei Geologi. 25-27 Settenbre.

Dal Cin, R., 1968. Pebble Clusters: their origin and utilization in the study of paleocurrents. Sedimentary Geology 2, 233-241.

Davis, G.H., Raynolds, S.J., 1996. Structural Geology of Rocks and Regions. Wiley and Sons, Inc. ISBN 0-47-52621-5.

De Celles, P.G., Giles, K.A., 1996. Foreland basin systems. Basin Research 8, 105-123.

De Celles, P.G., Gray, M.B., Ridgway, K.D., Cole, R.B., Srivastava, P., Pequera, N., Pivnik, D.A., 1991. Kinematic history of foreland uplift from paleocene synorogenic conglomerate, beartooth range, Wyoming and Montana. Bulletin of the Geological Society of America 103, 1458-1475.

Del Ben, A., Guarnieri, P., 2000. Neogene transpression in the Cefalù Basin (southern Tyrrhenian): comparison between land and marine data. Memorie della Società Geologica Italiana 55, 27-33.

Dercourt, J., Zonenshain, L.P., Ricou, L.E., Kazmin, V.G., Le Pichon, X., Knipper, A.L., Grandjacquet, C., Sbortshikov, I.M., Geyssant, J., Lepvrier, C., Pechersky, D.H., Boulin, J., Sibuet, J.C., Savostin, L.A., Sorokhtin, O., Westphal, M., Bazhenov, M.L., Lauer, J.P., Biju-Duval, B., 1986. Geologic evolution of the Tethys belt from the Atlantic to the Pamirs since the Lias. Tectonophysics 123, 241-315.
Dewey, J.F., Helman, M.L., Turco, E., Hutton, D.H.W., Knott, S.D., 1989. Kinematics of the western Mediterranean. In: Coward, M.P., Dietrich, D., Park, R.G. (Eds.), Alpine Tectonics: Geological Society Spec. Pub., 45, pp. 265-283.

Doglioni, C., Harabaglia, P., Merlini, S., Mongelli, F., Peccerillo, A., Piromallo, C., 1999. Orogens and slab vs. their direction of subduction. Earth-Science Reviews 45, 167-208.

Ferla, P., Alaimo, R., 1975. Dickite nelle Argille Variegate di Caltavuturo-Scillato (Madonie-Sicilia). Mineralogica et Petrographica Acta 20, 117-127.

Finetti, I.R., 2005. CROP project: deep seismic exploration of the central Mediterranean and Italy. In: Finetti, I.R. (Ed.), Atlases in Geoscience, 1. Elsevier, Amsterdam, pp. 1-794.

Flores, G., 1959. Evidence of slump phenomena (Olistostromes) in areas of hydrocarbons explorations in Sicily. Proc. 5th. World Petr. Congr., Sect. I. New York, pp. 259-275.

Ford, M., Williams, E.A., Artoni, A., Vergés, J., Hardy, S., 1997. Progressive evolution of a fault-related fold pair form growth strata geometries, Sant Llorenç de Morunys, SE Pirenees. Journal of Structural Geology 19, 413-441.

Galloway, W.E., 1975. Process framework for describing the morphologic and stratigraphic evolution of deltaic depositional systems. In: Broussard (Ed.), Deltas, models for exploration: Houston Geol. Soc.

Giunta, G., Nigro, F., Renda, P., 2000. Extensional tectonics during maghrebides chain building since late Miocene: examples from northern Sicily. Annales Societatis Geologorum Poloniae 69.

Grasso, M., 2001. The Apenninic-Maghrebian orogen in southern Italy, Sicily and adjacent areas. In: Finetti, I.R., Boccaletti, M., Bonini, M., Del Ben, A., Gelati, R., Papani, M., Sani, F. (Eds.), Crustal section based on CROP seismic data across the North Tyrrhenian-Northern Apennines-Adriatic Sea: Tectonophysics, 343, pp. 135-163.

Grasso, M., Butler, R.W.H., 1991. Tectonic controls on the deposition of Late Tortonian sediments in the Caltanissetta basin of central Sicily. Memorie della Società Geologica Italiana 47, 313-324.

Grasso, M., Lentini, F., Vezzani, L., 1978. Lineamenti stratigrafico-strutturali delle Madonie (Sicilia centro-settentrionale). Geologica Romana 17, 45-69.

Grasso, M., Manzoni, M., Quintili, A., 1987. Misure magnetiche sui Trubi della Sicilia orientale. possibili implicazioni stratigrafiche e strutturali. Memorie della Società Geologica Italiana 38, 459-474.

Guarnieri, P., (1998) Esempi di tettonica traspressiva: strutture e stili deformativi in Sicilia nord occidentale (Monti di Trabia - Termini Imerese). PhD Thesis, University of Catania.

Guarnieri, P., 2004. Structural evidence for deformation by block rotation in the context of transpressive tectonics, northwestern Sicily (Italy). Journal of Structural Geology 26 (2), 207-219.

Gugliotta C., (2010) L'evoluzione tortoniano-messiniana dell'avanfossa siciliana; interazione tra sedimentazione e tettonica. PhD Thesys, XXI Ciclo. Dipartimento di Geologia e Geodesia, Università degli Studi di Palermo, 236 pp.

Gugliotta, C., 2011. The "Camporeale wedge-top Basin" (NW Sicily; Italy) in the frame of the Late Miocene Sicilian Foreland Basin System; inferences from the Upper Tortonian-Lower Messinian Terravecchia Formation. Journal of Geodynamics 51, 378-397.

Gugliotta, C., 2012. Inner vs outer wedge-top sequences from the Late Miocene Sicilian Foreland Basin System. Journal of Geodynamics 55, 41-55, http://dx.doi.org/ 10.1016/j.jog.2011.11.002.

Gugliotta, C., Agate, M., 2010. Tectonically-enhanced deposition in the Late Tortonian Scillato Basin (N Sicily); a sequence stratigraphic view. Rend. online Società Geologica Italiana, 11.

Hardy, S., Poblet, J., 1995. The velocity description of deformation. Paper 2: sediment geometries associated with fault-bend and fault propagation folds. Marine and Petroleum Geology 12, 165-176.

Lentini, F., Carbone, S., Catalano, S., 1994. Main structural domains of the central Mediterranean region and their Neogene tectonic evolution. Bollettino di Geofisica Teorica ed Applicata 36, 141-144.

Lo Cicero, G., Di Stefano, E., Catalano, R., Sprovieri, R., Agate, M., Contino, A., Greco, G., Mauro, G., 1997. The Ciminna evaporitic basin cyclical sedimentation and eustatic control in a transpressive tectonic setting. In: Catalano, R. (Ed.), Time scales and basin dynamics. Sicily, the adjacent Mediterranean and other natural laboratories, 8th Workshop of the ILP Task Force "Origin of Sedimentary Basins", Palermo (Sicily), June 7-13, 1997.

Malinverno, A., Ryan, W.B.F., 1986. Extension in the Tyrrhenian Sea and shortening in the Apennines as a result of arc migration driven by sinking of the lithosphere. Tectonics 5, 227-245.

Miall, A.D., 1977. A review of the braided river depositional environment. Earth Science Review 13, 1-62.

Miall, A.D., 1978. Lithofacies types and vertical profile models of braided river deposits, a summary. In: Miall, A.D. (Ed.), Fluvial Sedimentology: Mem. Can. Soc. Petrol Geol., 5, pp. 597-604.

Miall, A.D., 1985. Architectural-elements analysis: a new method of facies analysis applied to fluvial deposits. Earth Science Review 22, 261-308.

Monaco, C., De Guidi, G., 2006. Structural evidence for Neogene rotations in the eastern Sicilian fold and thrust belt. Journal of Structural Geology 28.

Mutti, E., Tinterri, R., Di Biase, D., Fava, L., Mavilla, N., Angella, S., Calabrese, L., 2000 Delta-front associations of ancient flood-dominated fluvio-deltaic systems. Revista Sociedad Geologica Espana 13 (2), 165-190.

Mutti, E., Tinterri, R., Benevelli, G., Di Biase, D., Cavanna, G., 2003. Deltaic, mixed and turbidite sedimentation of ancient foreland basins. Marine and Petroleum Geology 20, 733-755.

Nigro, F., Renda, P., 2000. Un Modello Di Evoluzione Tettono-Sedimentaria Dell'avanfossa Neogenica Siciliana. Bollettino della Società Geologica Italiana 119. 
Ogniben L., (1960) Note Illustrative Dello Schema Geologico Della Sicilia NordOrientale. Riv. Min. Sic., 64-65: 183-212, 2 Tavv. Di Sez. Geol. 1:200.000. Palermo.

Ogniben, L., 1969. Schema introduttivo alla geologia del confine calabro-lucano. Memorie della Società Geologica Italiana 8, 453-763.

Oldow, J.S., Channel, J.E.T., Catalano, R., D'argenio, B., 1990. Contemporaneous thrusting and large-scale rotations in the western Sicilian fold and thrust belt. Tectonics 9 (4), 661-681.

Onofrio, V., Tropeano, M., Festa, V., Moretti, M., Sabato, L., 2009. Quaternary transpression and lacustrine sedimentation in the San Lorenzo area (Sant'Arcangelo Basin, Italy). Sedimentary Geology 222, 78-88.

Riba, O., 1976. Syntectonic unconformities of the Alto Cardener, Spanish Pyrenees: a genetic interpretation. Sedimentary Geology 15, 213-233.

Roure, F., Howell, D.G., Muller, C. And, Moretti, I., 1990. Late Cenozoic subduction complex of Sicily. Journal of Structural Geology 12 (2), 259-266.

Roure, F., Swennen, R., Casero, P., 2002. Tectonics and petroleum systems of the Sicilian foreland fold and thrust belt. Field trip guide: AAPG-IFP hedberg Research Conference, May 14-18, 2002 Palermo-Mondello (Sicily, Italy), pp. 6-9. Abstract vol.

Rust, B.R., 1978. Depositional model for braided alluvium. In: Miall, A.D. (Ed.), Fluvial Sedimentology: Mem. Can. Soc. Petrol. Geol., 5, pp. 605-625. Calgari.
Salvini, F., 2001. Daisy2, version2. 44b. The Structural Data Integrated Analyzer (free software). Dipartimento di Scienze Geologiche, Universita` degli Studi di 'Roma3', Rome.

Schmidt di Friedberg, P., 1962. Introduction a la géologié pétrolière de la Sicilie. Revue de l'Institut Français du Pétrole 17 (5), 635-669 (Paris)

Schmidt di Friedberg, P., 1964-65. Litostratigrafia petrolifera della Sicilia. Riv. Min. Sic. 88-90 and 91-93, pp. 1-80. Palermo.

Speranza, F. Maniscalco, R. Grasso, M., 2003. Pattern of orogenic rotations in centraleastern Sicily: implications for the timing of spreading in the Tyrrhenian Sea. Journal of the Geological Society of London 160, 183-195.

Valenti, V., 2010. Shallow structures at the outer Calabrian accretionary wedge (NW Ionian Sea): new insights from recently migrated reflection data. Terra Nova 22 (6), 453-462.

Zoetemeijer, R., Sassi, W., Roure, F., Cloetingh, S., 1992. Stratigraphic and kinematic modelling of thrust evolution, northern Apennines, Italy. Geology 30, 1035-1038. 